\title{
The genotypic and phenotypic impact of hypoxia microenvironment on glioblastoma cell lines
}

\author{
Lucy Wanjiku Macharia ${ }^{1,2}$, Wanjiru Muriithi' ${ }^{2,3}$, Carlos Pilotto Heming ${ }^{2,3}$, Dennis Kirii Nyaga ${ }^{2,4}$, Veronica Aran², \\ Marianne Wanjiru Mureithi ${ }^{5}$, Valeria Pereira Ferrer ${ }^{2}$, Attilio Pane ${ }^{3}$, Paulo Niemeyer Filho ${ }^{2}$ and Vivaldo Moura-Neto ${ }^{1,2^{*}}$ (D)
}

\begin{abstract}
Background: Glioblastoma is a fatal brain tumour with a poor patient survival outcome. Hypoxia has been shown to reprogram cells towards a stem cell phenotype associated with self-renewal and drug resistance properties. Activation of hypoxia-inducible factors (HIFs) helps in cellular adaptation mechanisms under hypoxia. Similarly, miRNAs are known to be dysregulated in GBM have been shown to act as critical mediators of the hypoxic response and to regulate key processes involved in tumorigenesis.

Methods: Glioblastoma (GBM) cells were exposed to oxygen deprivation to mimic a tumour microenvironment and different cell aspects were analysed such as morphological changes and gene expression of miRNAs and survival genes known to be associated with tumorigenesis.

Results: It was observed that miR-128a-3p, miR-34-5p, miR-181a/b/c, were down-regulated in 6 GBM cell lines while miR-17-5p and miR-221-3p were upregulated when compared to a non-GBM control. When the same GBM cell lines were cultured under hypoxic microenvironment, a further 4-10-fold downregulation was observed for miR-34-5p, miR128a-3p and 181a/b/c while a 3-6-fold upregulation was observed for miR-221-3p and 17-5p for most of the cells. Furthermore, there was an increased expression of SOX2 and Oct4, GLUT-1, VEGF, BCl-2 and survivin, which are associated with a stem-like state, increased metabolism, altered angiogenesis and apoptotic escape, respectively.

Conclusion: This study shows that by mimicking a tumour microenvironment, miRNAs are dysregulated, stemness factors are induced and alteration of the survival genes necessary for the cells to adapt to the micro-environmental factors occurs. Collectively, these results might contribute to GBM aggressiveness.
\end{abstract}

Keywords: Glioblastoma, Tumorigenesis, hypoxia microenvironment, miRNAs, Stem-like state

\section{Background}

Glioblastoma (GBM), a grade IV astrocytoma is the most common and fatal type of primary adult brain tumour $[1,2]$. Dismal overall prognosis remains for patients with

\footnotetext{
* Correspondence: vivaldomouraneto@gmail.com

${ }^{1}$ Programa de Pós-Graduação em Anatomia Patológica, Faculdade de Medicina da Universidade Federal do Rio de Janeiro - (PPGAP-UFR), Rio de Janeiro, Brazil ${ }^{2}$ Laboratório de Biomedicina do Cérebro- Instituto Estadual do Cérebro Paulo Niemeyer (IECPN), Rio de Janeiro, Brasil. Rua do Rezende, 156 - Centro, Rio de Janeiro, RJ 20231-092, Brasil

Full list of author information is available at the end of the article
}

GBM due to a local recurrence despite the concomitant treatment based on chemotherapy using temozolomide (TMZ), radiotherapy and surgery $[3,4]$. With treatment, the median survival of patients with GBM is approximately 14.6 months, and their 5 -year survival rate is $4-$ $5 \%[1,3,5]$. In the tumour mass, only a small fraction of cells known as glioblastoma stem cells (GSCs), is capable of initiating a new tumour due to their self-renewal capability and their resistance to chemo-radiotherapy [6, 7].

C The Author(s). 2021 Open Access This article is licensed under a Creative Commons Attribution 4.0 International License, which permits use, sharing, adaptation, distribution and reproduction in any medium or format, as long as you give appropriate credit to the original author(s) and the source, provide a link to the Creative Commons licence, and indicate if changes were made. The images or other third party material in this article are included in the article's Creative Commons licence, unless indicated otherwise in a credit line to the material. If material is not included in the article's Creative Commons licence and your intended use is not permitted by statutory regulation or exceeds the permitted use, you will need to obtain permission directly from the copyright holder. To view a copy of this licence, visit http://creativecommons.org/licenses/by/4.0/. The Creative Commons Public Domain Dedication waiver (http://creativecommons.org/publicdomain/zero/1.0/) applies to the data made available in this article, unless otherwise stated in a credit line to the data. 
Hypoxia is a fundamentally important hallmark of glioblastomas relative to lower-grade astrocytoma and is associated with tumour progression and a poor patient prognosis [8-10]. Pathologically, the hypoxia phenomenon is commonly represented in GBM by a distinctive feature including necrotic foci with surrounding cellular pseudopalisades and microvascular hyperplasia $[10,11]$. GBMs are often highly vascularized, and their increased cell proliferation/growth is linked to erratic tumour neovascularization. However, the vasculature is poorly organized and exhibits severe structural and functional abnormalities. Consequently, this leads to regions of the tumour experiencing a reduced supply of oxygen, known as hypoxia [10, 12]. Hypoxia triggers cellular adaptation, drives the selection of more aggressive tumour cells as well as the potentiation of the infiltration and migration of tumour cells [13, 14]. Similarly, the hypoxia microenvironment has been shown to maintain GSCs and promote reprogramming towards a cancer stem-like cell phenotype [15]. To cope with low oxygen availability, intracellular modifications occur in the cells including reprogramming of the metabolic and bioenergetic demands primarily through a number of oxygensensing pathways including the hypoxia-inducible factors (HIFs) family of transcription factors -dependent and -independent responses [16]. HIF comprise an oxygensensitive alpha subunit and a beta subunit. Under hypoxia, the alpha subunit is stabilized and translocated from the cytoplasm to the nucleus where it heterodimerizes with the constitutively expressed beta subunit $[16,17]$. HIF leads to the transcription of genes that regulate processes such as angiogenesis, glycolysis and invasion [8].

Among the non-coding RNAs, microRNAs (miRNAs) are the commonly studied RNAs [18] with a potential capacity of regulating up to $60 \%$ of the protein-coding genes [19]. Dysregulated expression of miRNAs has been observed in GBM making them a promising diagnostic biomarker [20]. Seven of the miRNAs used in this study were selected from previous studies as either upregulated or downregulated in glioblastoma samples. Studies have found miR-34 to be downregulated in GBM tissues as compared to healthy controls and to be a key regulator of tumour suppression [21, 22]. The highly conserved miR-34a has been reported to have multiple targets including Notch-1, Notch-2, CDK6, CCND1, MYC, BCL-2, c-Met $[21,23-25]$ and to be a transcriptional target of p53 $[26,27]$. The miRNA $128-3 p$ is a brain enriched miRNA, [28] that also appears to act as a tumour suppressor in glioblastoma whose expression is found reduced in human glioblastoma samples compared to controls devoid of the tumour, also correlating with aggressive human glioma subtypes [29-32]. The miR-128 has been shown to have various targets like
PDGFRA, EGFR [33] WEE1, E2F3a, [34, 35] ANGPTL6, Bmi-1 [29] and SUZ12 [36]. The miR-181 family are well known brain-enriched miRNAs [32] found downregulated in all grades of glioma samples compared to normal brain tissues [30, 31, 37] and predicts response to concomitant chemoradiotherapy with temozolomide in glioblastoma patients $[38,39]$. The miR-181a can target Bcl-2 [40, 41] while miR-181b and miR-181c can modulate the expression of EGFR [42] and the NOTCH2 pathway [43] respectively. On the other hand, miR-221 has been found upregulated in GBM versus normal brain tissue $[30,31]$. miR221 can regulate the STAT3/ Akt pathway, the tumour suppressor p2 $7^{\mathrm{Kip} 1}$ in glioma cells $[44,45]$ and can interfere with the p53/Bcl-2/ PUMA, p27Kip 1 and TGF- $\beta$ signalling $[46,47]$. Finally, The miR-17-92 is one of the best-characterized oncogenic miRNAs, a polycistronic miRNA cluster, designated as OncomiR-1 [48]. miR-17 is expressed at higher levels in glioma tissues than in normal brain tissues and is associated with poor patient prognosis [49] targeting PTEN and ATG7 [50, 51]. Additionally, a protooncogene, c-Myc [52-54] alongside the Notch and Sonic Hedgehog oncogenic signalling pathways [55] have been found to activate the transcription of the miR-17 family. An intertwined role between microRNAs, hypoxia and the stem cell state has been well explained in our previous work [56].

Oxygen concentration in the human brain ranges between approximately $4.6 \% \mathrm{O}_{2}$ in the healthy brain to $1.7 \% \mathrm{O}_{2}$ in a brain with a tumour [57]. GBM cell lines are traditionally cultured in vitro with an $\mathrm{O}_{2}$ tension of $20.9 \%$. These oxygen values are far from the experimental in vitro conditions which mean that cell culture is performed in hyperoxic rather than physoxic conditions of respective organs or the physiological oxygen tension reflected in the tumour microenvironment $[58,59]$. By growing our cells in a hypoxia microenvironment, we mimicked a glioblastoma hypoxic niche allowing for a more in-depth study of the cellular adaptations. In the present study, we were able to shed light on the morphological changes, miRNAs alterations and prosurvival genes in response to hypoxia $\left(1 \% \mathrm{O}_{2}\right)$ reflective of possibly the true events that occur in an actual tumour microenvironment. The importance of our work relies on the fact that the miRNA expression profile has not been previously established using our GBM cell lines. Similarly, even though there are advances in the field of tumour hypoxia, in vitro experiments continue to be conducted mainly under normoxic microenvironments that may have influenced previously reported results. The evidence provided by the present study may help to support the development of future effective therapies and the discovery of new therapeutic targets. 


\section{Methods \\ Reagents}

All components used for the culture media, DMEM/F12 Dulbecco's Modified Eagle Medium/Nutrient Mixture were supplied by Gibco ; HEPES was supplied by Life Technologies (São Paulo, Brazil) and fetal bovine serum (FBS) was supplied by Invitrogen (Paisley, UK). Penicillin and Streptomycin were purchased from Gibco. Fungizone was purchased from Bristol-Myers Squibb (Princeton, NJ). Glucose was purchased from Merck (Darmstadt, Germany). All culture plates and flasks were obtained from TPP (Trasadingen, Switzerland). Rabbit anti-glial fibrillary acidic protein (\#Z0334) and mouse anti-vimentin (\#M0725), antibodies were purchased from Dako (Glostrup, Denmark). Protease and phosphatase inhibitors were supplied by Roche (Indianapolis, IN). Antibodies for Oct-4A (\#2840) and SOX2 (\#D6D9) were purchased from Cell Signaling Technology (Beverly, MA). The anti-GLUT-1(\#07-1401) and anti-HIF$1 \alpha$ (MAB5382) antibody were purchased from Millipore Corporation (Single Oak drive, CA, USA) Anti-VEGFA (\#ab46154) and anti-Survivin (\#ab76424) anti-BCL2 (\#ab33862) antibodies were purchased from Abcam (Cambridge, MA, USA). The secondary antibodies, conjugated to Alexa Fluor 488(\#A-11008, A-21131) and 546 (\#A-11010, A-21124) or HRP conjugated anti-mouse (\#G-21040) or rabbit (\#G-21234) antibodies were purchased from Thermo Scientific (Rockford, USA). PVDF membranes were purchased from Millipore (Billerica, MA). The 4', 6-diamidino-2-phenylindole (DAPI) was obtained from Sigma (MA, USA). $2 \times$ Laemmli buffer and $\beta$-mercaptoethanol were purchased from Bio-Rad (São Paulo, Brazil).

\section{Cells and culture conditions}

The GBM02, GBM03, GBM11 and GBM95 glioblastoma cell lines were established and characterized in our laboratory "Laboratório de Morfogênese Celular -ICBUFRJ", as previously described by Faria et al., [60], while U87 and T98G are ATCC cell lines. The GBM cells were maintained in Dulbecco's modified Eagle's medium (DMEM/F12) supplemented with $10 \%$ fetal bovine serum (FBS) and maintained in normoxia chamber set at $37{ }^{\circ} \mathrm{C}$ in an atmosphere containing 95\% air and $5 \% \mathrm{CO}_{2}$ for the normoxic culture and at $1 \% \mathrm{O}_{2}$ in a hypoxia chamber (Thermo scientific) for the hypoxia culture for $72 \mathrm{~h}$. A non-GBM control (human astrocyte cell line) was used as control for the miRNA experiments. The H2 human astrocyte cell line was kindly provided by Dr. Luciana Romão from the Institute of Biomedical Sciences - Federal University of Rio de Janeiro (ICB-UFRJ) and was maintained in the same culture conditions as the GBM cell lines.

\section{Western blotting}

GBM cells were cultured in $75 \mathrm{~cm}^{3}$ Petri dishes and incubated for $72 \mathrm{~h}$ in either normoxic or hypoxic conditions. When the cells were ready, the media was poured out and the Petri dishes were rinsed three times with cold 1X PBS. The Petri dishes were then maintained in ice after which a lysis buffer (1X RIPA (RIPA-25 mM Tris• $\mathrm{HCl}, \mathrm{pH} 7.6,150 \mathrm{mM} \mathrm{NaCl}, 1 \% \mathrm{NP}-40,1 \%$ sodium deoxycholate and $0.1 \%$ sodium dodecyl sulfate (SDS), supplemented with protease inhibitor was added and then scraped off using a cell scraper. The lysates were sonicated and then centrifuged at $4{ }^{\circ} \mathrm{C}, 10.000 \mathrm{~g}$ for 15 min. The supernatants were analysed for protein content using the Bradford method [61] according to the manufacturer's instructions. Samples were mixed with sample buffer $(2 \mathrm{x}$ Laemmli sample buffer and 2Mercaptoethanol) in a ratio of $1: 1$ and heated for $5 \mathrm{~min}$ at $95{ }^{\circ} \mathrm{C}$. For the immunodetection of proteins, 30-50 $\mu \mathrm{g}$ of total cell proteins were separated by electrophoresis on $10 \%$ SDS polyacrylamide gels and transferred to polyvinylidene difluoride (PVDF) membranes. The PVDF membranes were then blocked with $5 \%$ non-fat milk in Tris-buffered saline with $0.1 \%$ Tween-20 (TBS-T) for 1 $h$, incubated with specific primary antibodies overnight at $4{ }^{\circ} \mathrm{C}$, washed with TBS-T five times for five minutes each before incubation with horseradish peroxidaseconjugated antibodies. The signals of anti-SOX2/ OCT4A (Cell Signaling Technology, 1:1000), anti-Glut-1 (Millipore, 1:500) anti-VEGF (Abcam,1:1000), anti- Survivin (Abcam 1:1000), anti-GFAP (DAKO, 1:1000), antiVimentin (Dako, 1:1000). Super-signal West Pico chemiluminescent substrate (Thermo Scientific) and Supersignal West Femto maximum sensitivity substrate (Thermo Scientific) was used to reveal the bands. Bands were obtained using ChemiDoc MP System (BioRad, Benicia, CA, USA) a multiplex fluorescent and chemiluminescence system. The densitometric analyses were performed using ImageJ software (Wayne Rasband, National Institutes of Health, Bethesda, MD), and the values obtained represent the ratio between the immunodetected protein and Tubulin (the loading control). A detailed explanation on the quantification performed can be found in the supplementary file.

\section{Immunocytochemistry (ICC)}

For ICC analysis, $1 \times 10^{4}$ cells in 300ul DMEM/F12 were plated on coverslips placed on a 24-well plate in either normoxic or hypoxic conditions for $72 \mathrm{~h}$. The cells were fixed using 4\% PFA after achieving a desirable confluence. The cells were then rinsed with $1 \%$ PBS and permeabilization was done using $0.1 \%$ triton. The slips were then incubated in 5\% BSA for $30 \mathrm{~min}$ to minimize nonspecific binding. Incubation with the primary antibody was done overnight at $4{ }^{\circ} \mathrm{C}$ with either anti-SOX2/ 
OCT4 (Cell signaling technology, 1:400), anti-HIF1alpha (Millipore, 1:500), anti-Glut-1 (Millipore, 1:500) anti-VEGF (Abcam,1:500:) anti-Survivin (Abcam, 1:500) anti-BCL2 (Abcam,1:500), anti-Ki67 (Dako, 1:150), antiGFAP (DAKO, 1:500), and anti-Vimentin (Dako, 1:100). The slips were then rinsed using PBS before incubating with secondary antibodies conjugated with Alexa Fluor 488 (goat anti-mouse/rabbit; 1:2000) or Alexa Fluor 546 (goat anti-rabbit; $1: 2000$ ) for $2 \mathrm{~h}$ at room temperature. They were then washed with $1 \mathrm{X}$ PBS, before staining with DAPI. Finally, the slips were rinsed with PBS before mounting on glass slides using Fluoromount-G antifading agent (Emsdiasum). The cells were imaged using DMI8 advanced fluorescence microscopy (Leica Microsystems, Germany) and the fluorescence intensity of individual cells was measured and analysed using ImageJ software (NIH, USA). Negative controls were included in every ICC staining, where a selected number of slips (under both conditions) were stained with only the secondary antibody conjugated to the fluorophore that was used to adjust the microscope intensity, or baseline settings, before reading the results. A detailed explanation on the method employed for the ICC quantification is given in the supplementary file of this manuscript.

\section{RT-qPCR}

Total RNA was extracted from GBM cells using Trizol Reagent (Ambion, Life Technologies) and the PureLink ${ }^{\circ}$ RNA Mini Kit (Invitrogen, Thermo Scientific) following the manufacturer's instructions. Sample RNA purity was estimated using (Nanodrop lite, Thermo Scientific) spectrophotometer where a ratio of 1.8 to 2 was considered pure. One microgram of the total RNA, pool RT microRNA primer (custom made) and SuperScript ${ }^{\mathrm{TM}}$ III Reverse Transcriptase (SS III, Invitrogen, Life technologies) were used to perform the cDNA synthesis. Quantitative real-time PCR (qRT-PCR) was done using Power SYBR green PCR master mix (Applied biosystems, Thermofisher scientific) and custom-made microRNA primers from Integrated DNA Technologies (IDT). The primers used are described in Table 1.

The run was done using CFX96 Real-Time System (Bio-Rad). Melt curves were included in every run and the assays were performed in triplicates. Endogenous RNA U6 (RNU6) was used as a control for the normalization of mature miRNAs while actin was used for the for the normalization of the gene expression. Analysis of the miRNAs expression was calculated using the $2{ }^{-{ }^{\Delta}} \mathrm{Cq}$ method [62]. The data was obtained from three independent experiments and analysed using Graph pad prism.

\section{Statistical analysis}

The experimental data are expressed as the mean \pm standard deviation (SD) of three independent replicates. Statistical differences between two groups were evaluated by the Student's t-test. Those between more than two groups were subjected to analysis of variance (ANOVA) with Dunnett's as a post-test using GraphPad Prism 5.0 statistics software (GraphPad Software, Inc., La Jolla, CA). $P<0.05$ was considered statistically significant.

\section{Results}

The expression profile of miRNAs in 6 GBM cell lines compared to human astrocyte

Dysregulated expression of miRNAs has been observed in GBM making them a promising diagnostic biomarker [20]. Similarly, miRNAs expression is tissue or cellspecific and this expression profile has not been established for our GBM cell lines. We evaluated seven miRNAs reported from previous studies, miR-34 [21, 22], miR-128 [29-32], miR-181 family [30, 31, 37], miR-221 $[30,31]$ and miR-17 [49], as either upregulated or downregulated in glioblastoma samples. Therefore, we cultured the GBM cell lines and a human astrocyte control cell line under normoxic conditions for $72 \mathrm{~h}$ and performed the qRT-PCR using the SYBR green platform.

Table 1 Primers and sequences

\begin{tabular}{|c|c|c|}
\hline Name & Forward primer (5'- 3') & Reverse Primer (5'- 3') \\
\hline miR- 34-5p & ACACTCCAGCTGGGTGGCAGTGTCTTAGCT & CTCAACTGGTGTCGTGGAGTCGGCAATTCAGTTGAGAGACAACC \\
\hline miR-128-3p & ACACTCCAGCTGGGTCACAGTGAACCGGTC & CTCAACTGGTGTCGTGGAGTCGGCAATTCAGTTGAGAGAAAGAGAC \\
\hline miR-221-3p & ACACTCCAGCTGGGAGCTACATTGTCTGCT & CTCAACTGGTGTCGTGGAGTCGGCAATTCAGTTGAGAGGAAACCCA \\
\hline miR- $17-5 p$ & ACACTCCAGCTGGGCAAAGTGCTTACAGTG & CTCAACTGGTGTCGTGGAGTCGGCAATTCAGTTGAGAGCTACCTGC \\
\hline miR-181a-3p & ACACTCCAGCTGGGACCATCGACCGUUGAT & CTCAACTGGTGTCGTGGAGTCGGCAATTCAGTTGAGAGGGTACAAT \\
\hline miR-181b-5p & ACACTCCAGCTGGG- AACATTCATTGCTGTC & CTCAACTGGTGTCGTGGAGTCGGCAATTCAGTTGAGAGACCCACCG \\
\hline miR-181c-5p & ACACTCCAGCTGGGAACATTCAACCTGTCG & CTCAACTGGTGTCGTGGAGTCGGCAATTCAGTTGAGAGACTCACCG \\
\hline Universal reverse & & CTCAAGTGTCGTGGAGTCGGCAA \\
\hline SNU6 & GCTTCGGCAGCACATATACTAAAAT & CTCAACTGGTGTCGTGGAGTCGGCAATTCAGTTGAGAGCGTTCCA \\
\hline Human Actin & ATGAAGATCAAG ATCATTGCTCCT & ACATCTGCTGGAAGGTGGACA \\
\hline
\end{tabular}


Results from our study found miRNAs 34-5p, 128-3p, $181 \mathrm{a} / \mathrm{b} / \mathrm{c}$ to be downregulated while miRNAs $221-3 \mathrm{p}$ and $17-5 p$ to be upregulated when compared to the astrocytes. Among all the cell lines analysed, the miRNA expression profile was more homogenous for miR-34-5p and 128-3p (Fig. 1). Our results agreed with previous reports.

\section{The effect of hypoxia on the expression of markers of GBM aggressiveness}

Hypoxia is a GBM common phenomenon and to cope with low oxygen availability, intracellular modifications occur in the cells primarily via the HIF transcription factor [16]. For our study, a hypoxia culture model was used to create a hypoxic niche in order to reflect what happens in the brain microenvironment of a patient with GBM [57]. Thus, we used this model to understand the cellular mechanisms of the GBM cells in vitro. The cells were cultured under normoxia ( $21 \%$ oxygen) and under hypoxia ( $1 \%$ oxygen) for $72 \mathrm{~h}$, and different factors associated with GBM aggressiveness were investigated as follows.

\section{Cells acquired hypoxia as confirmed by HIF-1a translocation to the nucleus}

Before evaluating the effects of hypoxia, we had to confirm the acquisition of hypoxia by the cells. It is known that under hypoxia, the HIF alpha subunit is usually stabilized and translocated from the cytoplasm to the nucleus where it heterodimerizes with the beta subunit $[16$,

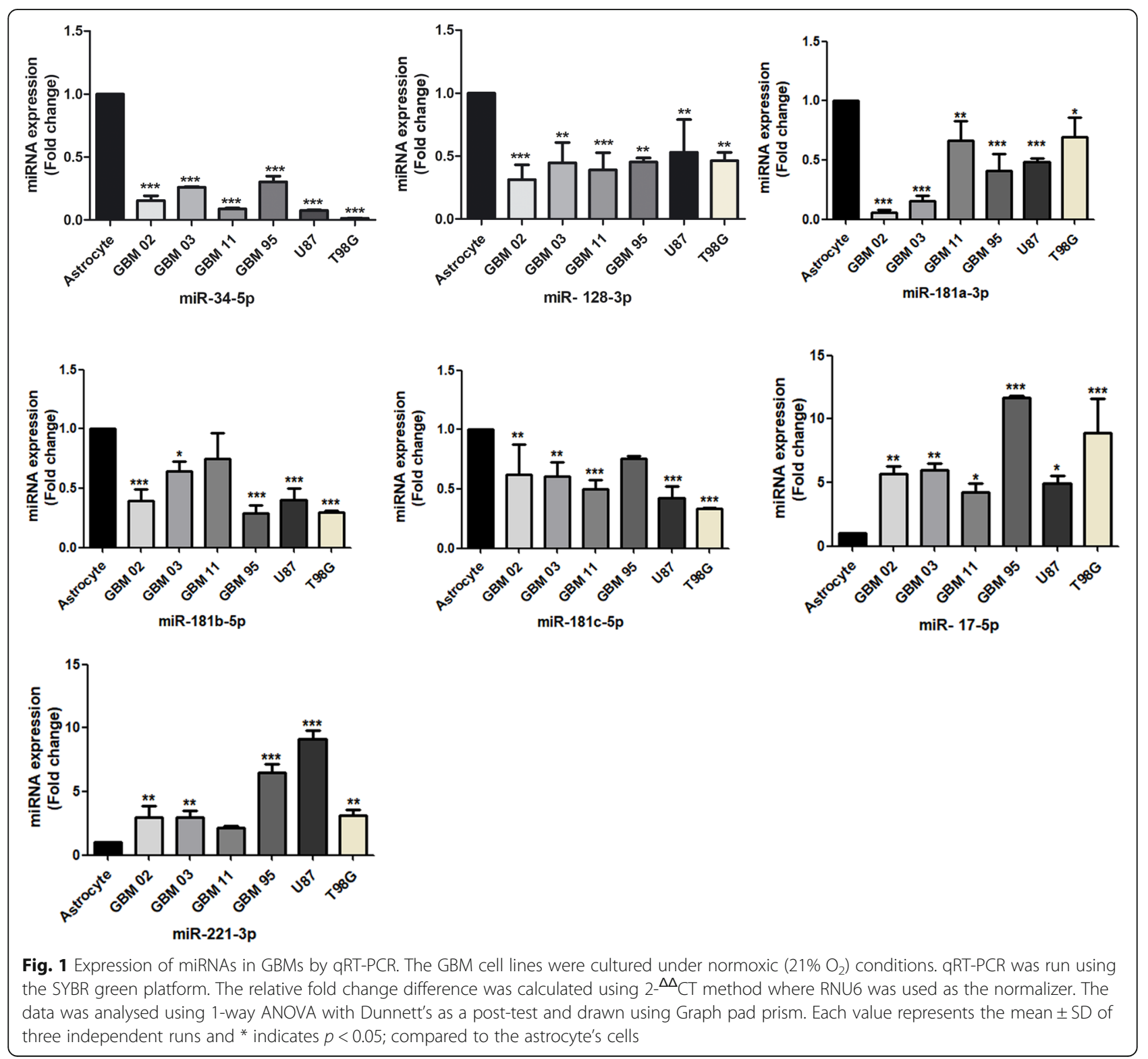


17]. Based on this fact, our cells showed a significant HIF- $1 \alpha$ translocation in the nucleus by immunocytochemistry staining confirming that our cells acquired the hypoxia microenvironment (Fig. 2).

\section{Hypoxia microenvironment induced morphological changes in GBM cells}

Cells have been reported to undergo intracellular modifications to cope with low oxygen availability. To test this fact, we cultured cells under normoxia $\left(21 \% \mathrm{O}_{2}\right)$ and under hypoxia $\left(\begin{array}{ll}1 \% & \mathrm{O}_{2}\end{array}\right)$ and photographed them after $72 \mathrm{~h}$ of cell culture without interference. Our results suggested the cells to be viable under both microenvironmental conditions with notable changes in GBM11, GBM95, U87 and T98G under hypoxia $(\mathrm{H})$ induction. The GBM95H had a population of cells with fibrous-like edges. The T98GH had cells with a reduced spindle morphology or elongations as compared to their counterparts grown in normoxia. The GBM11H and U87H had an outstanding phenotypic morphology consisting of clustered or sphere-like cells with "well-defined borders" resembling to what we observe when we culture the GBM cells in stem-cell defined media during the initial days of transformation into an undifferentiated state. There were no notable morphological differences in GBM02 and GBM03 (data not shown) (Fig. 3).

\section{Hypoxia induced increased expression of stem cell markers}

Hypoxia has been associated with reprogramming towards a stem-like cell phenotype and an increased expression of the stem-cell markers [15]. To study this effect, we cultured our cells under hypoxia microenvironment and analysed the differential expression of the stem cell markers, SOX2 and OCT4. Our results showed an upregulated expression of SOX2 and OCT4 in all the cells under hypoxia conditions (Fig. 4a - c). The high expression of SOX2 and OCT4 was also observable in GBM11N by immunocytochemistry (Fig. 4a \& b).

\section{Hypoxia increased GLUT-1 associated with metabolism}

The glucose transporter 1 (GLUT-1), plays a role in metabolism during glycolysis by facilitating the entry of glucose into the cytoplasm of the cell. In the context of limited oxygen, the cell makes up for the limited energy by increasing its glucose supply that would translate to increased GLUT-1. To test this fact, we evaluated the

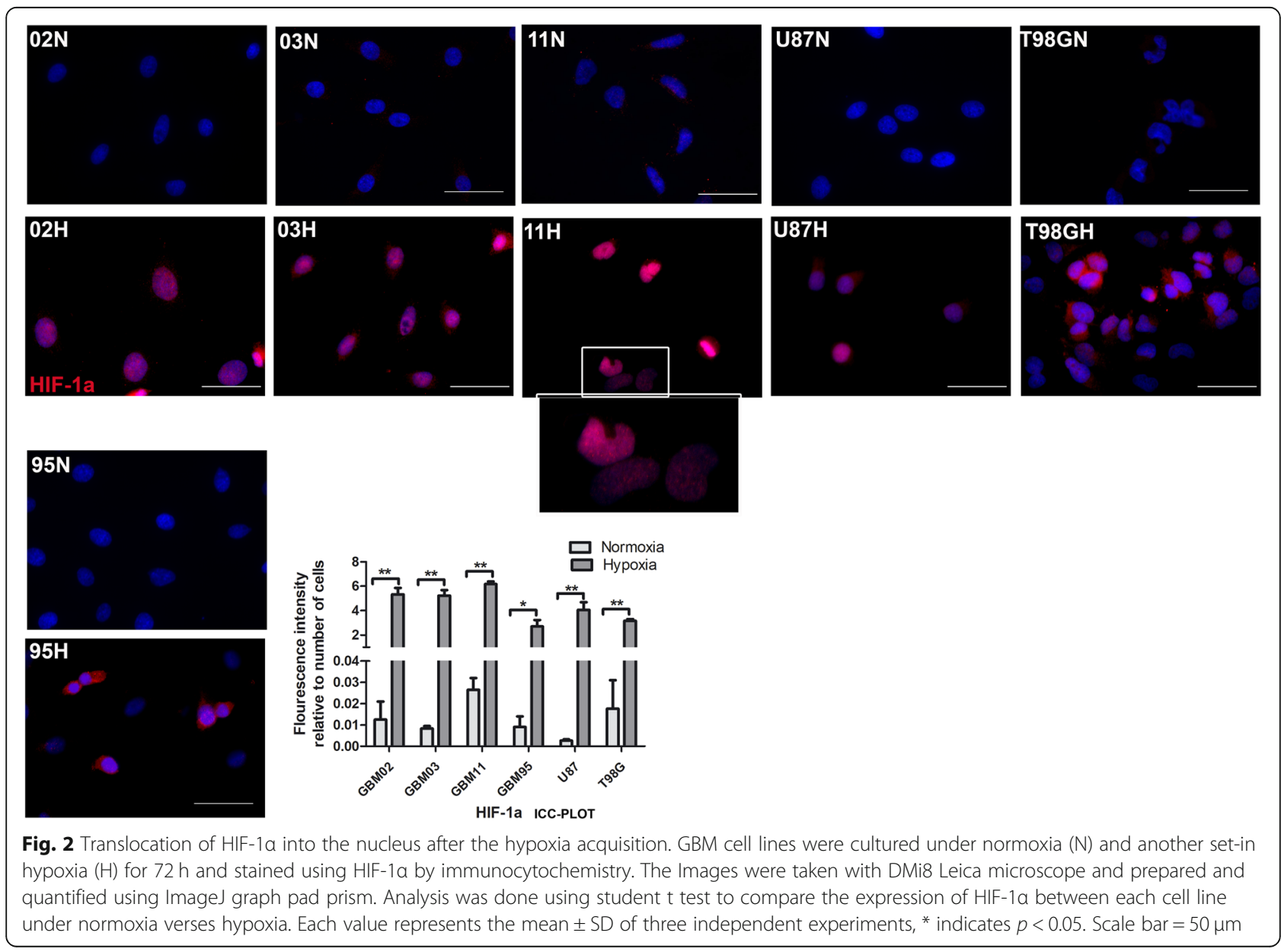



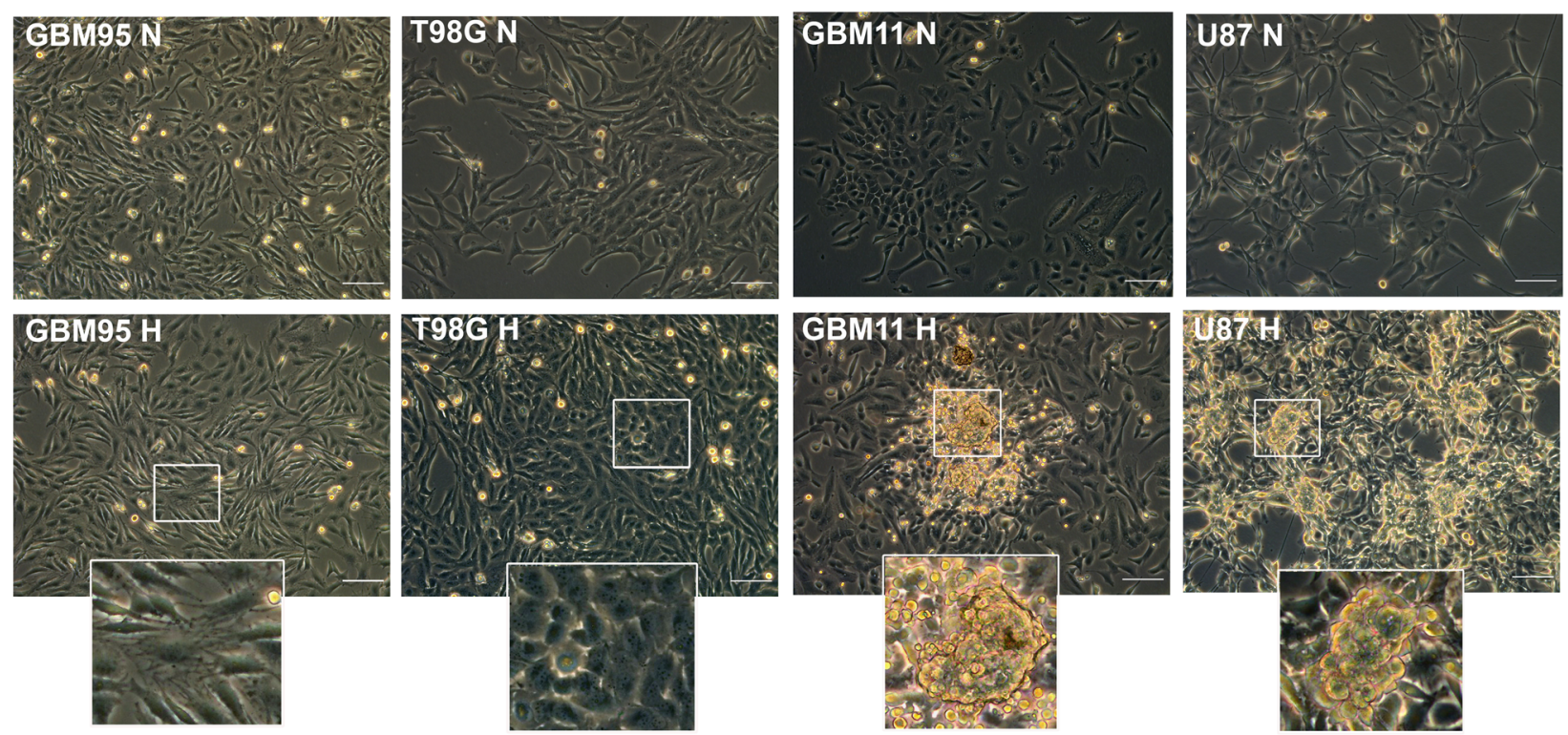

Fig. 3 Morphological changes of cells under hypoxia microenvironment. GBM cells (GBM02, GBM03, GBM11, GBM95, U87 and T98G) were cultured in DMEM/F12 with 10\% FBS. One batch of the cells was maintained at $37^{\circ} \mathrm{C}$ in a humidified $5 \% \mathrm{CO} 2$ and $95 \%$ air atmosphere for normoxia (N) while the other at 1\% O2 for hypoxia $(\mathrm{H})$. The photos were taken using DMl 8 Leica microscope and edited using image J.

Scale bar $=200 \mu \mathrm{m}$

expression of GLUT-1 in our cells cultured under both the microenvironments. Data from our work showed an expression of GLUT-1 under both microenvironments. Hypoxia induced an upregulation of GLUT-1 in all our tested cells (Fig. 5a \& b). We also observed different staining patterns between our cells, where GBM $02 \mathrm{H}$, $03 \mathrm{H}$ and $95 \mathrm{H}$ showed a different staining pattern from the one observed in U87H, T98G and GBM11H. The U87H, T98G and GBM11H had suggestively larger cells (Fig. 5a).

\section{Hypoxia increased VEGF associated with angiogenesis}

Altered microvasculature is a hallmark of GBM. GBMs proliferate, and expand beyond their existing blood supply, creating hypoxic niches. This results in the upregulation of angiogenic factors like VEGF that induces the formation of blood vessels. We analysed the differential expression of VEGF, a pro-angiogenic factor, in both conditions. All our GBM cells expressed VEGF as reported but the expression was further upregulated under the hypoxia microenvironment (Fig. 6a \& b).

\section{Increased expression of the anti-apoptotic and proliferation markers under hypoxia}

GBM's aggressiveness is partially attributed to its decreased apoptosis or apoptotic escape. We evaluated the expression of two anti-apoptotic proteins survivin and Bcl-2 to test this hypothesis. All cells expressed the antiapoptotic factors in both microenvironments, but the expression was enhanced further under hypoxia (Fig. 7a-c).
Survivin is also a member of the inhibitor of apoptosis protein (IAP) family and is expressed either as a cytoplasmic or nuclear pool, being involved in the regulation of cell division and apoptosis [63]. We were able to observe the differential expression of survivin in our cells. GBM02, 03 and 95 expressed survivin as a cytoplasmic pool while GBM11, U87 and T98G expressed survivin as a nuclear pool (Fig. 7a). Cytoplasmic survivin has been shown to have antiapoptotic properties [64] while nuclear survivin has been highlighted to play an important role in chromosomal segregation during mitosis spindle [65]. The Bcl-2 expression was localized in the cytoplasm and was found upregulated in our cells under hypoxia (Fig. 7c). Ki-67 is a nuclear protein that is preferentially expressed during all active phases of the cell cycle (G1, S, G2 and M-phases) but is absent in resting cells (Go-phase). We evaluated the expression of Ki-67, a marker of proliferation, from our cell lines and the expression was clearly visible in all our cells under normoxia and hypoxia suggesting that our cells did not go into the resting or quiescent phase during the $72 \mathrm{~h}$ of culture (Sup Fig. 1).

\section{Enhanced expression of cytoskeleton proteins}

Glial fibrillary acidic protein (GFAP) is a class III intermediate filament (IF) protein that constitutes a portion of the cytoskeleton. It is a cell-specific marker that, during the development of the central nervous system, distinguishes astrocytes from other glial cells. All our GBM cell lines expressed GFAP as expected since they are of 

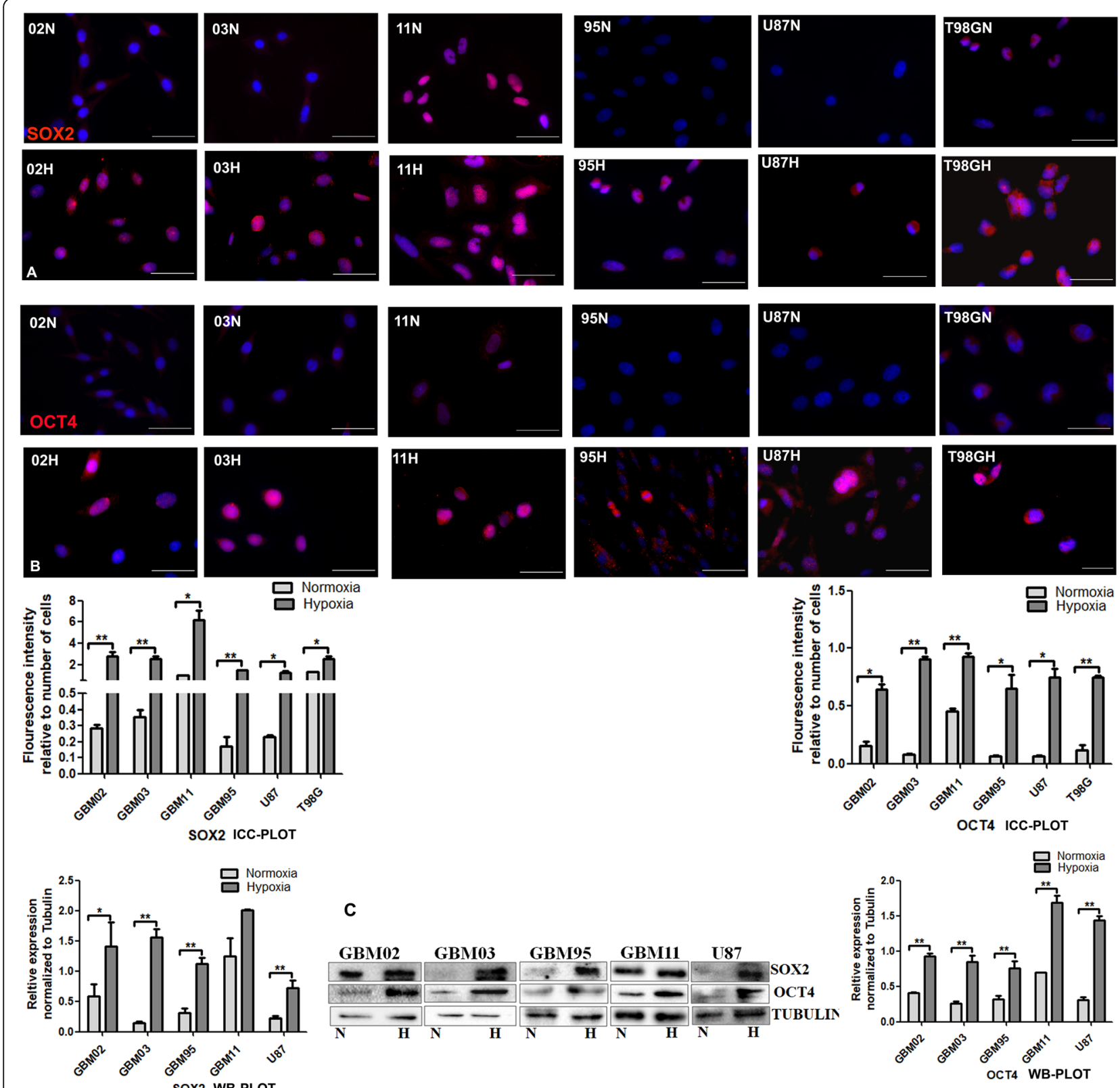

C
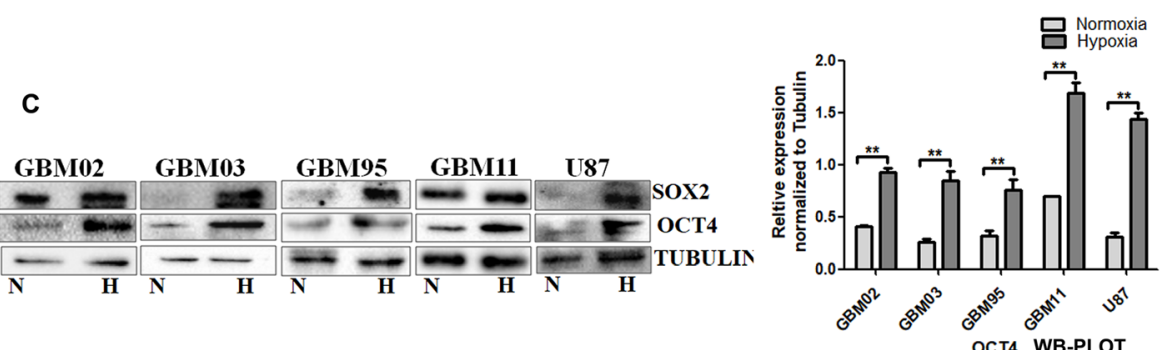

Fig. 4 Enhanced the expression of the stem cell markers. A \& B. Cells were cultured under normoxia $(\mathrm{N})$ and in hypoxia $(\mathrm{H})$ for $72 \mathrm{~h}$ and stained for Sox2 and Oct4 by immunocytochemistry. The Images were taken with DMi8 Leica microscope and prepared and quantified using ImageJ. C. Western blotting was done by the SDS-PAGE method and densitometry done using ImageJ. The relative expression was normalized to tubulin. Analysis was done using student $t$ test using graph pad prism. Each value represents the mean \pm SD of three independent experiments, * indicates $p<0.05$. Scale bar $=50 \mu \mathrm{m}$. Representative Western blots are shown as cropped images. Full-length blots are presented in Additional File 2 (Fig. S2)

astrocytic origin (Fig. 8a \& b). On the other hand, vimentin is an intermediate filament protein type III, which also forms part of the cytoskeleton of vertebrate cells and is expressed by proliferating cells. Our results also showed vimentin to be significantly expressed in all GBM cell lines (Fig. 8c and d). Both GFAP and vimentin were suggestively upregulated under the hypoxic microenvironment.
Hypoxia microenvironment induced dysregulation of miRNAs expression

Hypoxia microenvironment has been documented to alter the expression of miRNAs [56]. To investigate this hypothesis, cell lines were cultured again under normoxia $\left(21 \% \mathrm{O}_{2}\right)$ and hypoxia $\left(1 \% \mathrm{O}_{2}\right)$ for $72 \mathrm{~h}$. Results in Fig.1 show miR-34-5p, 128-3p and 181a/b/c to be downregulated while miR-221-3p and 17-5p to be upregulated 

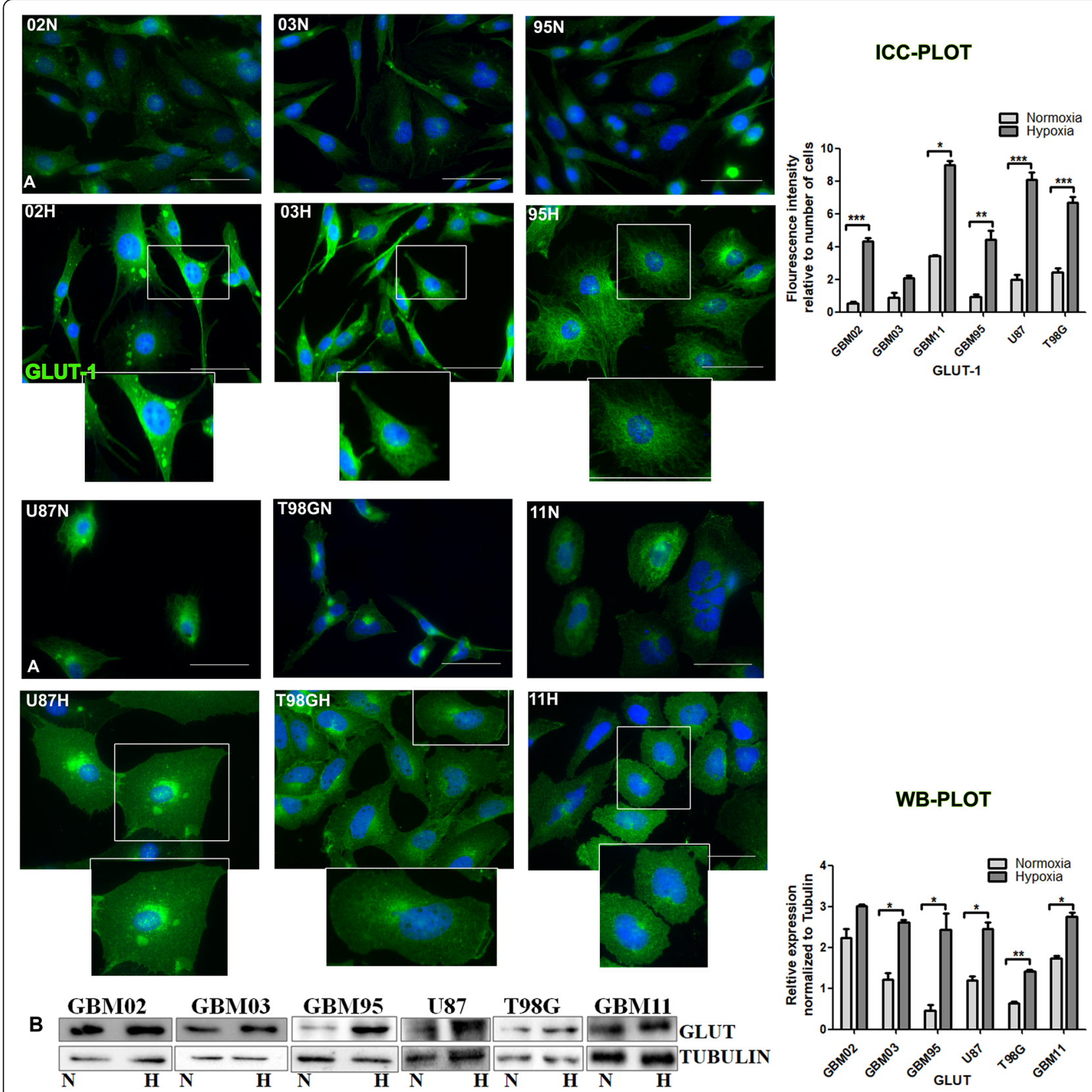

Fig. 5 Enhanced expression of GLUT-1 under hypoxia microenvironment. A. Cells were cultured under normoxia (N) and another set in hypoxia (H) for $72 \mathrm{~h}$ and stained for GLUT-1 by immunocytochemistry. The Images were taken with DMi8 Leica microscope and quantified using ImageJ. B. Western blotting was done by the SDS-PAGE method and densitometry done using ImageJ. The relative expression was normalized to tubulin. Data was analysed using student $t$ test by graph pad prism. Each value represents the mean \pm SD of three independent experiments, ${ }^{*}$ indicates $p<0.05$. Scale bar $=50 \mu \mathrm{m}$. Representative Western blots are shown as cropped images. Full-length blots are presented in Additional File 3 (Fig. S3)

when a comparison was made between a GBM and a non GBM cell line (astrocytes). After hypoxia induction, miR-34-5p and miR-181a/b/c had a further 2-3-fold downregulation while miR-128-3p had a 4-5-fold downregulation. Similarly, miR-17-5p and 221-2p were further upregulated by a 3 -fold (Fig. 9).

\section{Discussion}

Glioblastoma is a fatal type of primary adult brain tumour with a dismal overall prognosis $[1,2]$. The molecular mechanisms underlying the GBM aggressiveness are still unclear. In this study, we investigated the expression profile of specific miRNAs, stemness and 


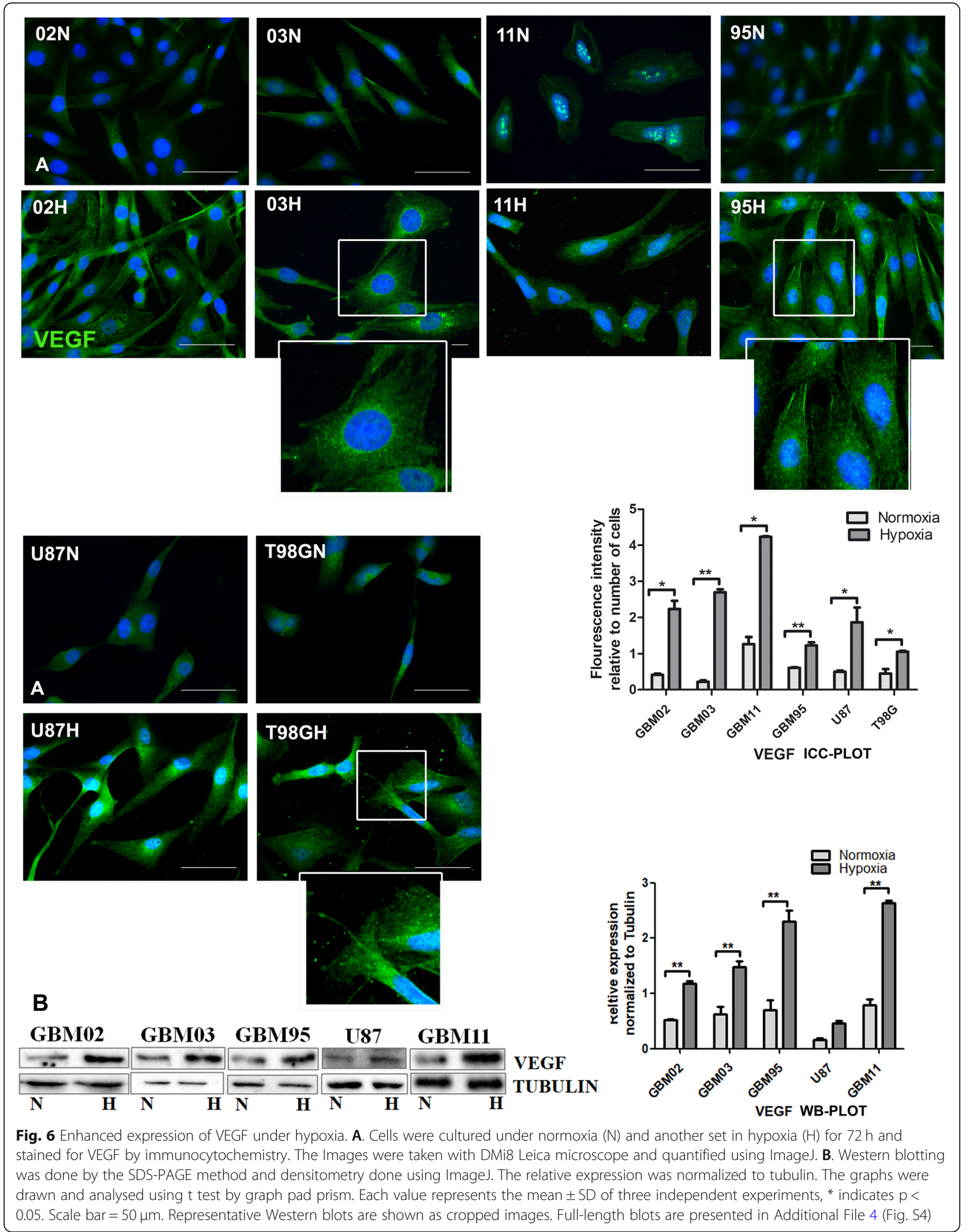




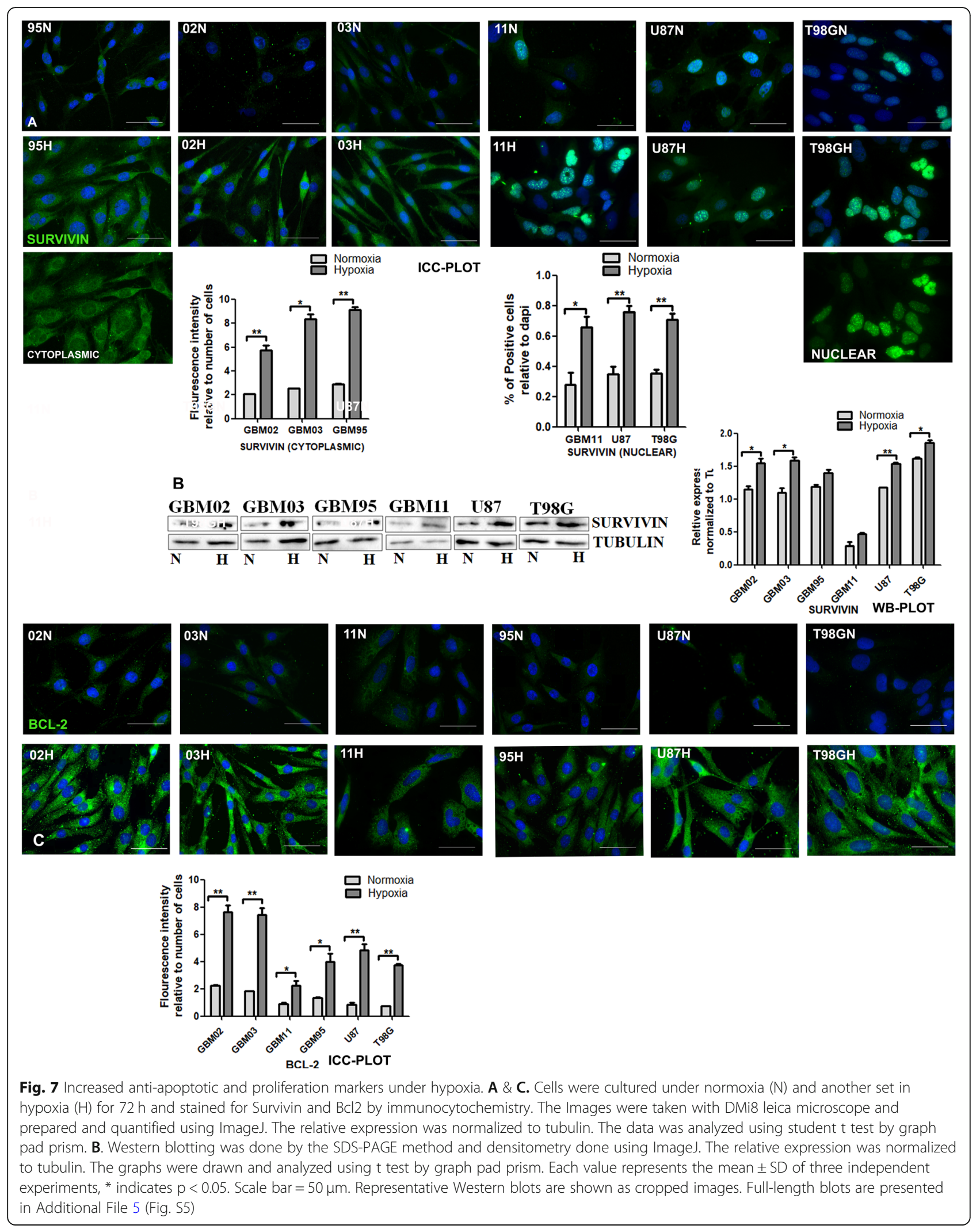




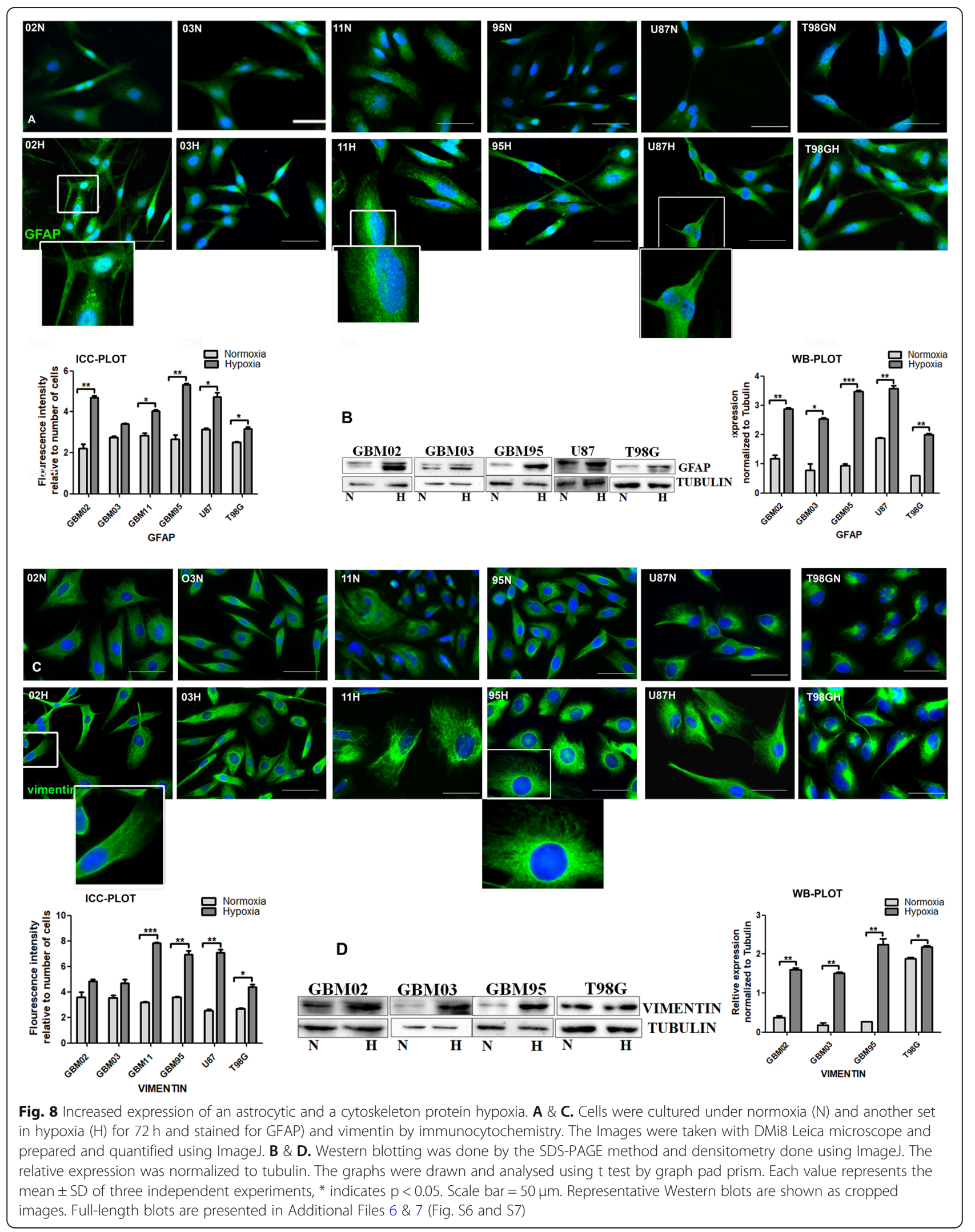




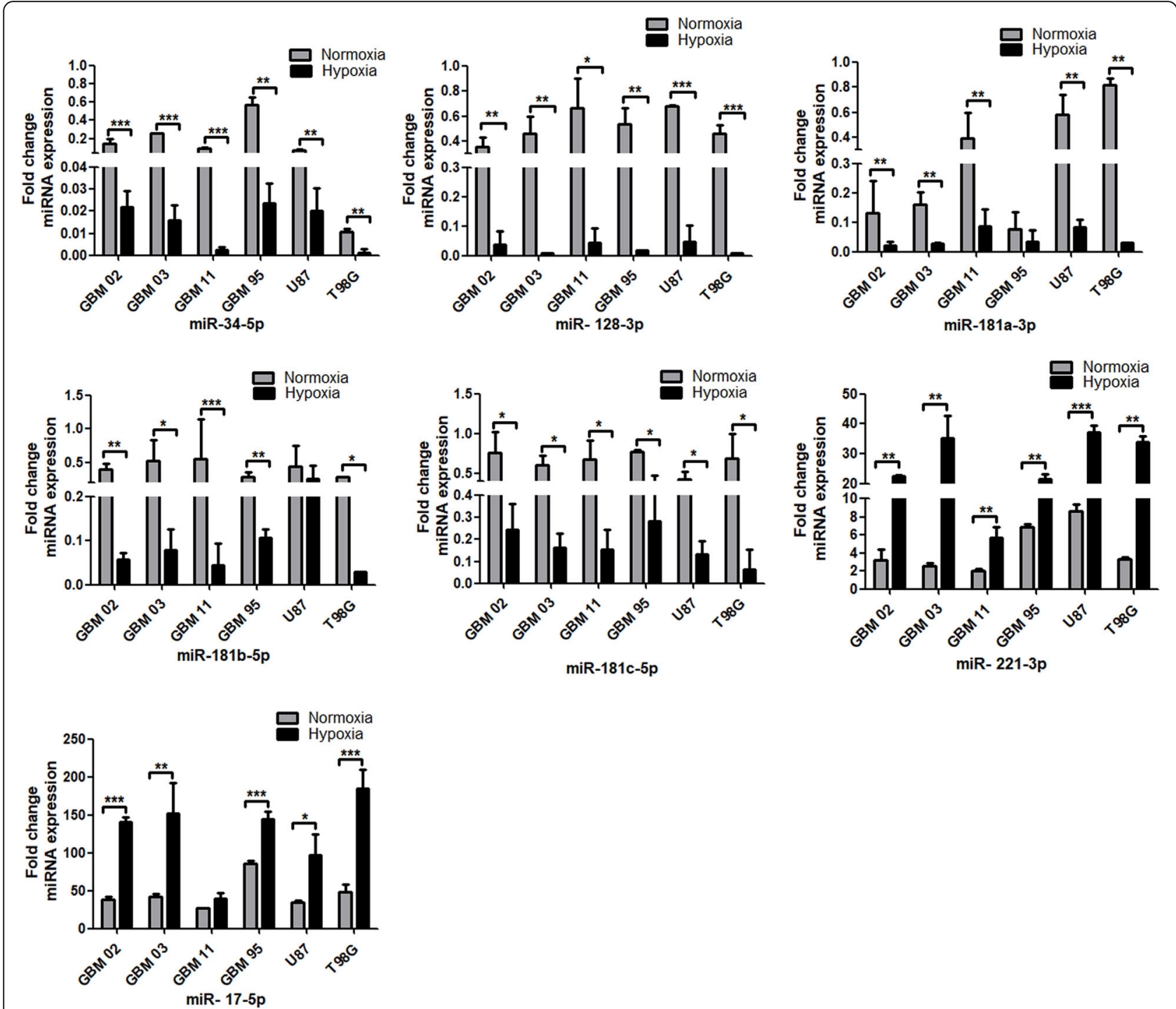

Fig. 9 Dysregulation of miRNAs in GBMs under hypoxia by RT-qPCR. The GBM cell lines were cultured under hypoxic conditions. RT-qPCR was run using the SYBR green platform. The relative fold change difference was calculated using ${ }_{2}{ }^{\Delta \Delta}$ Cq method where RNU6 was used as the normalizer. The graphs were drawn and analysed using $t$ test by graph pad prism. Each value represents the mean \pm SD of three independent runs and * indicates $p<0.05$; compared to the astrocytes grown in either normoxia or hypoxia conditions

survival genes in GBMs grown under normoxia or hypoxia conditions. Results from our study show miR-34$5 \mathrm{p}, 128-3 \mathrm{p}$ and $181 \mathrm{a} / \mathrm{b} / \mathrm{c}$ to be downregulated whereas miR- 221- $3 p$ and 17-5p to be upregulated when compared to astrocytic cells, a non-GBM control. These results agree with what has been reported previously.

Hypoxia is a main feature of GBM $[10,11]$ being associated with poor prognosis [9]. Many intracellular modifications allowing cell adaptation to the low $\mathrm{O}_{2}$ availability are primarily controlled by the transcription factor system of the hypoxia-inducible factors (HIFs) [66-68]. In agreement with other studies, we were able to observe an increased expression of HIF- $1 \alpha$ when we cultured our cells under hypoxia microenvironment, consequently resulting to an increased expression of SOX2, OCT4, VEGF, GLUT-1, Bcl-2, survivin, GFAP and vimentin. The upregulation of HIF under hypoxia microenvironment has been shown to induce the expression of known pluripotent stemness factors, such as KLF4, MYC, OCT4, SOX2, and NANOG [69], to reprogram towards a cancer stem cell (CSC) phenotype and to influence the expansion of CSC populations [70]. This is similar to our observations where we found an increase in stemness factors, OCT4 and SOX2, which were upregulated under hypoxia. Additionally, hypoxia microenvironment has been shown to induce metabolic reprogramming [71, 72], alter angiogenesis [73] and induce cells apoptotic escape [74, 75]. Findings from our study 
showed an increased expression of GLUT-1 that plays a role in metabolism, increased VEGF that plays a role in angiogenesis, increased BCL-2 and survivin that plays a role in apoptotic escape, all of which were further upregulated under hypoxia microenvironment. Additionally, our results showed differential expression of survivin either as a cytoplasmic or a nuclear pool. The significance, or potential functions of surviving, in different cellular localizations is still a matter of debate. While cytoplasmic survivin has been shown to have anti-apoptotic properties [76], nuclear survivin has been shown to play a role in mitosis [77]. An inverse correlation between the cytoplasmic expression of survivin and cell apoptosis in GBMs has been reported, thus supporting an antiapoptotic function of the cytoplasmic form of survivin [78]. Shirai et al. reported nuclear survivin expression to be a poor prognosis predictor in GBM [79], while Saito and colleagues reported that the simultaneous expression of survivin in the nucleus and in the cytoplasm correlated with a poor prognosis in high-grade astrocytoma, including GBM [80]. More experiments would be needed to confirm the specific roles played by the two survivin expression pools in our cell lines.

It is important to highlight that HIF- $1 \alpha$ can also be subjected to negative regulation by tumour suppressors such as Von Hippel-Lindau (VHL) and (PTEN) [51]. Additionally, miRNAs can also regulate the tumour suppressors that negatively regulate HIF- $1 \alpha$. This has been shown by a study that found that MiR-17 induced HIF$1 \alpha$ activation in response to stress by targeting PTEN in GBM cells. Inactivation of PTEN influenced the overexpression of HIF- $1 \alpha$, leading to cascade reactions in angiogenesis and migration [51]. Although we found an upregulated expression of miR-17 and HIF- $1 \alpha$, a correlation study between the two was not performed. Moreover, the PTEN expression profile has not been established from our cells to accurately link PTEN and HIF- $1 \alpha$. It is known from previous studies that the PTEN's loss of function also results in HIF- $1 \alpha$ activation by dysregulation of the PI3K/AKT pathway, especially in GBM cells [81]. Our results revealed an upregulation of HIF- $1 \alpha$ and miR-17 after hypoxia induction but a direct correlation between miR-17, PTEN and HIF- $1 \alpha$ from our cell lines await further clarification.

We also show that hypoxia influenced the morphology of our GBM cells. There were observable morphological changes in GBM11, GBM95, U87 and T98G under hypoxia microenvironment. The GBM95H had a mixed population of cells with some showing fibrous-like edges, whereas the T98GH had cells with a reduced spindle morphology or elongations and were more clustered as compared to their counterparts grown in normoxia. The GBM11H and $\mathrm{U} 87 \mathrm{H}$ had an outstanding phenotypic morphology consisting of clustered or sphere-like cells with "well-defined borders" with no evidence of necrosis. The GBM11H and U87H clustered morphology was like what we observed when culturing GBM cells in stem cell defined media during the early days of conversion from a differentiated to an undifferentiated state. There are limited studies describing the accurate effects of hypoxia on the morphological aspects of the cells. A study by $\mathrm{Li}$ and colleagues showed that after incubation of U87 cells, $\mathrm{U} 251$ cells and $02 \mathrm{GBM}$ in $1 \% \mathrm{O}_{2}$ for $72 \mathrm{~h}$, the processes were absent, and oval cells aggregated in masses with no evidence of necrosis [82]. Similarly, a study that exposed U87, SNB75 and U251 cells to hypoxia $\left(1 \% \mathrm{O}_{2}\right)$ for $72 \mathrm{~h}$ found a marked morphological difference in U87 and SNB75 where the cells had a more elongated morphology and were more loosely clustered than in normoxia cultured cells [83]. More studies on this area are needed to accurately explain the morphological changes observed under the hypoxia microenvironment.

Studies suggest that stress signals are responsible for altered miRNA expression and functions [84-86]. Some miRNAs can modify gene expression by cross-talking with the tumour micro-environment, and their expression can be altered in turn by distinct stress conditions such as hypoxia, oxidative stimulation or radiation [8789]. Hypoxia inducible factor 1 has been hypothesized to regulate a panel of miRNAs, whereas some of miRNAs also target HIF-1 [90]. Our data revealed that when the GBM cells were cultured under hypoxia conditions the levels of miR-34-5p, 128a-3p and 181a/b/c increased, while miR-221-3p and 17-5p were downregulated. A direct relationship between miRNA expression levels and the genes SOX2, OCT4, VEGF, GLUT-1, Bcl-2, Survivin, GFAP, Ki-67 and vimentin was evaluated using bioinformatics tools (Fig. 10). In agreement with previous studies, we found target sequences for miR-34-5p and miR181a-5p, miR-181b-5p and miR-181c-5p in the 3' UTR of the Bcl-2 gene suggesting that these miRNAs might directly regulate $\mathrm{Bcl}-2$ and be responsible for its upregulation in hypoxia conditions. However, a target sites for miR-17-5p is present in the 3' UTR of HIF1A and VEGF-A, yet both this miRNA and its targets are upregulated in GBM cells under hypoxia regimens. Furthermore, there was no direct inter-relationship between other genes and miRNAs investigated in this study. It is possible that these miRNA-based regulatory mechanisms might involve additional factors and control levels. For instance, increased expression levels of miR-17 in glioblastoma cultured under stress conditions are known to cause downregulation of the transcription factor PTEN. In turn, reduced PTEN results in the upregulation of HIF $1 \alpha$ and VEGF [51]. Therefore, additional experiments will be necessary to fully understand the relationship between the miRNAs and protein-coding genes that we find to be affected by hypoxia conditions in GBM 


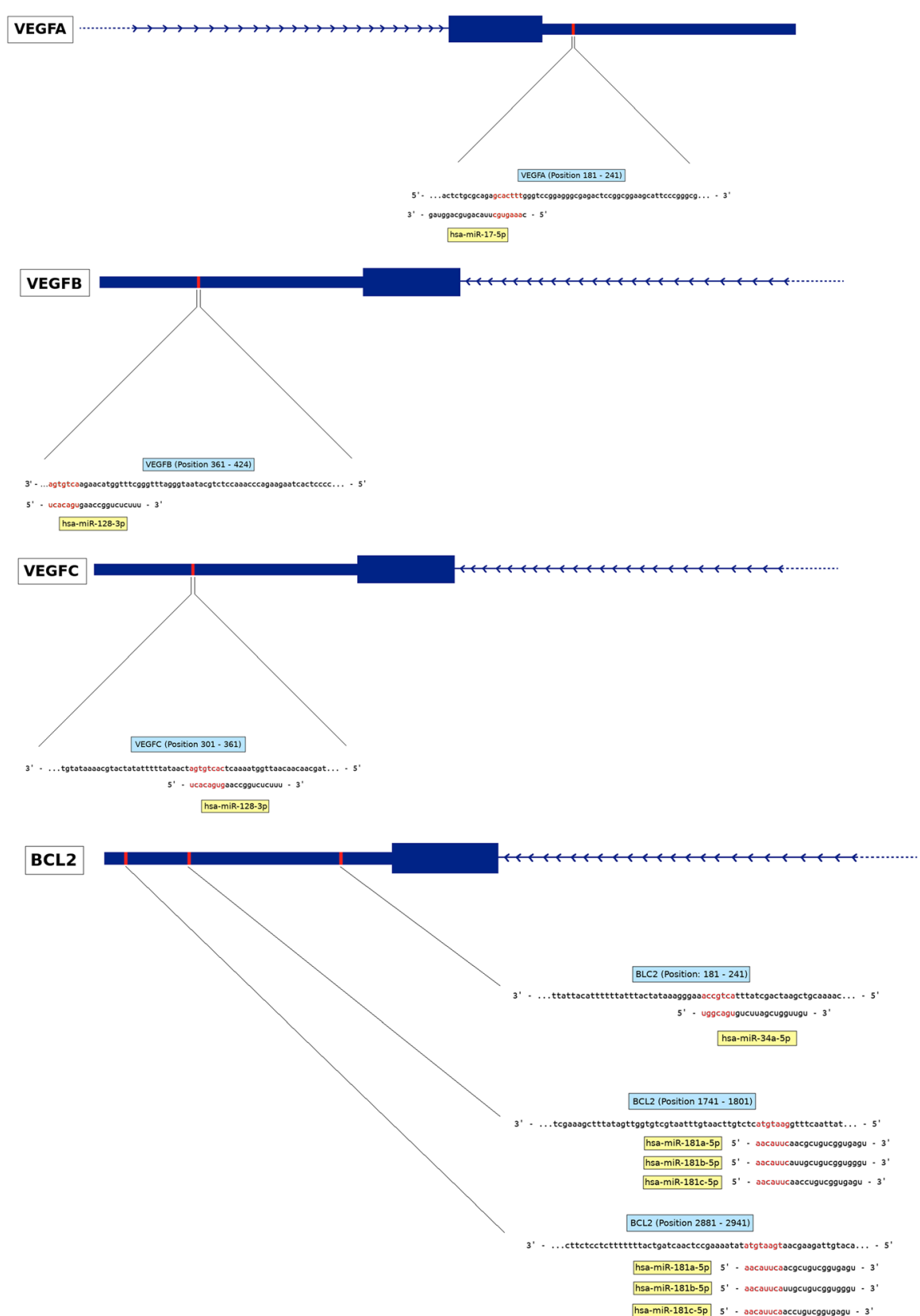

HIF1A

HIF1A Position (1081 - 1141)

$5^{\prime}$ - ... caaaatacaatgtttgattttatgcactttgtcgctattaacatcctttttttcatgtag ...

3' - gauggacgugacauucgugaaac - 5'

hsa-miR-17-5p

Fig. 10 (See legend on next page.) 
(See figure on previous page.)

Fig. 10 Bioinformatic analysis of the inter-relationship between the study miRNAs and genes. By using miRDB and TargetScan we confirmed previous findings showing that target sequences for miR-34-5p and miR-181a-5p, miR-181b-5p and miR-181c-5p are present in the $3^{\prime}$ UTR of the BCL-2 gene. Similarly the targets for miR-17-5p were found in the 3' UTR of HIF1A and VEGF-A. The target sequences for miR-128-3p were present in the $3^{\prime} U T R$ of VEGF-B and VEGF-C

cells. The tumour-suppressor protein, p53, lies at a nexus of cellular pathways that sense DNA damage, cellular stress (nutrient deprivation, hypoxia etc), oncogenic activation and improper mitogenic stimulation [91]. In response to such signals, p53 induces growth arrest, promotes apoptosis, blocks angiogenesis, or mediates DNA repair in a context-dependent manner [92]. In this sense, p53 has been shown to repress miR-17-92 transcription and consequently sensitizing cells for hypoxia-induced apoptosis [93]. However, our results have found miR-17 belonging to the miR-17-92 cluster and upregulated under hypoxia.

Genes encoding miRNAs in the miR-34 family are direct transcriptional targets of $\mathrm{p} 53$, whose induction by DNA damage and oncogenic stress depends on p53 expression both in vitro and in vivo. Studies have shown that ectopic expression of miR-34 induces cell cycle arrest in both primary and tumour-derived cell lines [27] which is consistent with the observed ability of the miR-34 family to play a role in the TP53 tumour suppressor function causing cell cycle

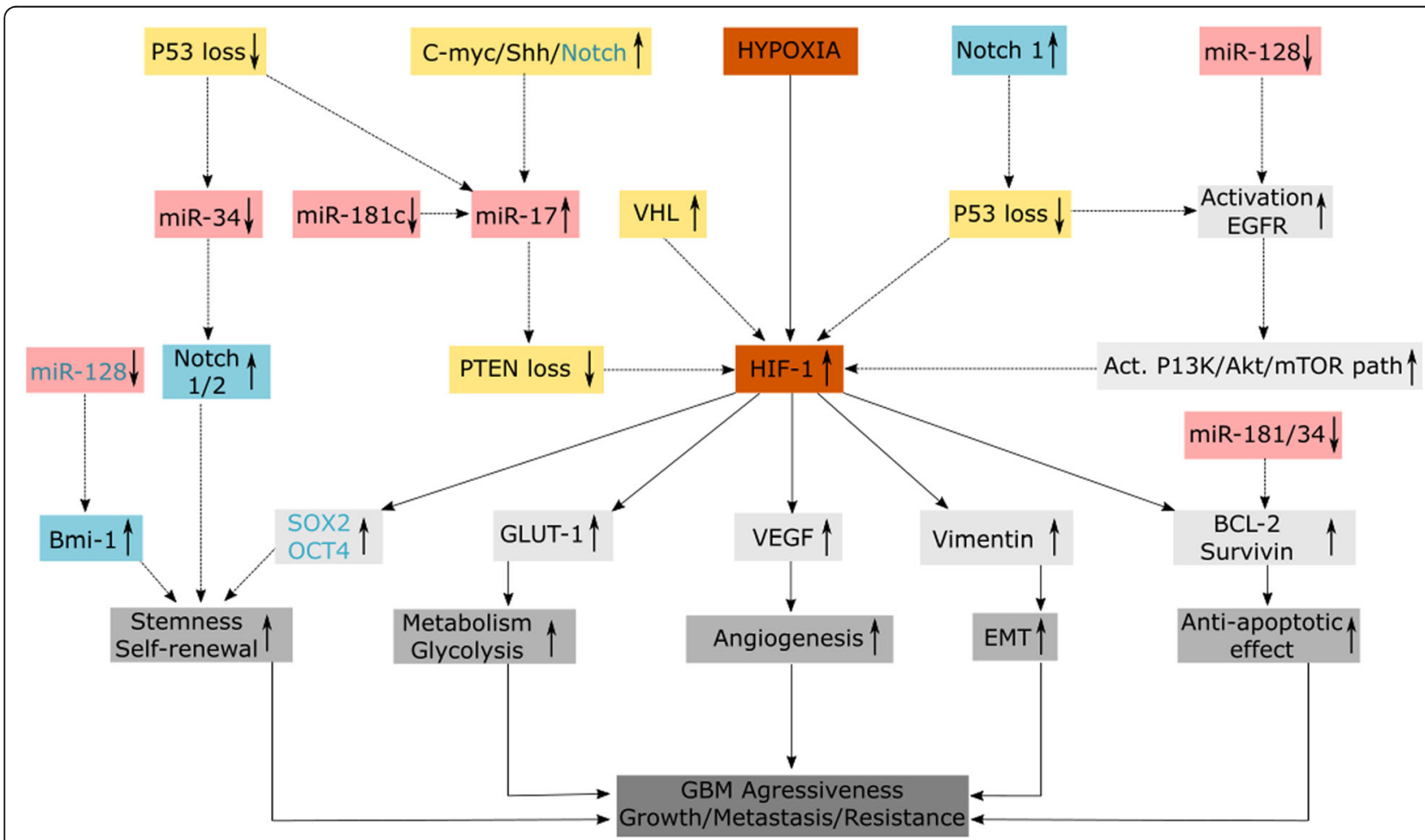

Fig. 11 Summary figure. The continuous arrows show findings derived from our results while the dotted arrows represent the summary obtained from previous published works. Under hypoxia microenvironment, HIF-1a was upregulated similar to its downstream targets associated with stemness (SOX2, OCT4), metabolism (GLUT-1), angiogenesis (VEGF), EMT transitioning (Vimentin) and anti-apoptosis (Bcl-2, survivin). The miR-34, 128 and 181 were found downregulated from our study similar to what has been reported. Previous works have associated the same miRNAs with key tumour suppressor or oncogenes which can also influence their activation directly or indirectly. Additionally, the miRNAs can also influence the expression of the tumour suppressor or oncogenes. In this manner, miR-34 has been reported to target multiple oncogenes including C-MET, NOTCH 1 and 2, BCL-2 and CDK6 in gliomas. Additionally, P53 has been shown to influence miR-34 expression. An oncogene cmyc has also been reported to directly activate the transcription of miR-17 family. Oncogenic signalling pathways, such as those of Notch and Sonic Hedgehog, have also been shown to activate miR-17-92 in cancer. Most of the key tumour's suppressors are known to have loss of function mutations that could also influence the expression of the miRNAs and the HIF. That means HIF-1a can also be subjected to the negative regulation by tumour suppressors such as Von Hippel-Lindau (VHL) and (PTEN). Additionally, some miRNAs can regulate the tumour suppressors that negatively regulate the HIF-1a. This has been shown by a study that found that MiR-17 induced HIF-1a activation in response to stress by targeting PTEN in GBM cells. Also, p53 that acts as negative transcriptional regulator of the miR-17-92 cluster under hypoxia is found mutated in the GBM 
arrest and apoptosis [24, 27, 94]. Similarly, p53 that acts as a negative transcriptional regulator of the miR-17-92 cluster and a positive transcriptional regulator of the miR-34 is found mutated in a variety of GBM $[95,96]$. Interestingly, miR-128 has been reported to be downregulated in response to hypoxia [90] which is in agreement with our observation. Despite the emergence of numerous studies on hypoxia-regulated miRNAs (HRMs) the function of HRMs remains to be elucidated. The correlation between the tumour suppressors and the oncogenes with the miRNAs from our cell lines awaits further confirmation. Similarly, we aim to test patient samples in the future.

The evidence provided from the present study highlights the influence of the hypoxia microenvironment on various aspects of the GBM tumour cells and this may help to advocate for the laboratory experiments to be conducted in a microenvironment reflective of the tumour's niche, thus representing a more accurate method.

Figure 11 summarises all the results for a clear comprehensive overview.

\section{Conclusions}

This study demonstrated a functional link between hypoxia, a well-documented tumour microenvironment factor, and miRNA expression. Moreover, we show that hypoxia controls the expression of several tumour genes that play a role in stemness, metabolism, angiogenesis, and anti-apoptosis, which are all involved in GBM tumorigenesis. Taken together, our findings comprehensively illustrate the effect of the hypoxia microenvironment on GBM cells in vitro, but in vivo studies are still required to compare the specific mechanism underlying this observation. Hypoxia culture could represent a closer culture model reflective of the brain microenvironment of a patient with glioblastoma, a factor that should be considered when conducting assays in the pursuit of identifying therapeutic targets and novel treatments.

\section{Abbreviations}

ANOVA: Analysis of variance; BSA: Bovine serum albumin; DMEM: Dulbecco's modified Eagle's medium; FBS: Foetal bovine serum; GFAP: Glial fibrillary acidic protein Glioblastoma; GBM: Glioblastoma stem cells (GSCs); GLUT1: Glucose transporter 1; H: Hypoxia; HIFs: Hypoxia-inducible factors; IF: Intermediate filament; miRNAs: microRNAs; N: Normoxia; PRC2: Polycomb Repressor Complex; PVDF: Polyvinylidene difluoride; RNU6: RNA U6; SDS: Sodium dodecyl sulphate; TMZ: Temozolomide; TBS-T: Tris-buffered saline with $0.1 \%$ Tween-20; VEGF: Vascular endothelial growth factor; VHL: Von Hippel-Lindau (VHL)
}

\section{Supplementary Information}

The online version contains supplementary material available at https://doi. org/10.1186/s12885-021-08978-z.

Additional file 1 Expression of the marker of proliferation under different microenvironments. A. Cells were cultured under normoxia ( $N$ ) and another set in hypoxia $(\mathrm{H})$ for $72 \mathrm{~h}$ and stained for Kl67. The Images were taken with DMi8 Leica microscope and prepared and quantified using ImageJ. Western blotting was done by the SDS-PAGE method and densitometry done using ImageJ. The relative expression was normalized to tubulin. The graphs were drawn and analysed using t test by graph pad prism. Each value represents the mean \pm SD of three independent experiments, ${ }^{*}$ indicates $p<0.05$. Scale bar $=50 \mu \mathrm{m}$.

Additional file 2 : Fig. S2. Full-length Western-blots for Fig. 4C. Additional file $\mathbf{3}$ : Fig. S3. Full-length Western-blots for Fig. 5B. Additional file 4 : Fig. S4. Full-length Western-blots for Fig. 6B. Additional file 5 : Fig. S5. Full-length Western-blots for Fig. 7B. Additional file $\mathbf{6}$ : Fig. S6. Full-length Western-blots for Fig. 8B Additional file 7 : Fig. S7. Full-length Western-blots for Fig. 8D.

\section{Acknowledgements}

We are thankful to the African Academy of Sciences (AAS) for the endless support and the continued mentorship. This opportunity was a result of the collaboration that exist between AAS and the Brazilian Academy of Sciences and for that we are grateful. The authors would also like to thank the members of the Laboratório de Biomedicina do Cérebro (LBMC) and the Associação Mahatma Gandhi for their support.

\section{Authors' contributions}

The study conceptualization and design were done by LWM and VMN. The data collection, analysis and interpretation were done by LWM, WM, AP, CPH and DNK. Preparation of the manuscript draft was done by LWM while the review, revision and final editing of the manuscript was done by LWM, VMN, VA, VPF, AP, PNF and MWM. The work was supervised by VMN. Funding acquisition was done by PNF and VMN. All the authors read and approved the final version of the manuscript.

\section{Funding}

This study was supported by the Brazilian agencies: Conselho Nacional de Desenvolvimento Científico e Tecnológico (CNPa), Coordenação de Aperfeiçoamento de Pessoal de Nível Superior (CAPES), Fundação de Amparo à Pesquisa do Rio de Janeiro (FAPERJ), and Ary Frauzino Foundation for Cancer Research. The funding agencies had no role in the study design, data collection, data analysis or interpretation.

\section{Availability of data and materials}

The datasets used and/or analysed during the current study are available from the corresponding author on reasonable request.

\section{Declarations}

\section{Ethics approval and consent to participate}

Primary human glioblastoma cell cultures (GMBs) were derived from tumours obtained from patients who had given written consent at the time. All procedures were approved by the local Ethics Committee at the Centre for Health Sciences at the Federal University of Rio de Janeiro (Protocol N ${ }^{\circ}$. DAHEICB 015) and by the Brazilian Ministry of Health Ethics Committee (CONEP Protocol N ${ }^{\circ}$. 2340) and were performed in accordance with the 1964 Helsinki declaration and its later amendments.

\section{Consent for publication}

Not applicable.

\section{Competing interests}

The authors declare no conflict of interest.

\section{Author details}

'Programa de Pós-Graduação em Anatomia Patológica, Faculdade de Medicina da Universidade Federal do Rio de Janeiro - (PPGAP-UFR), Rio de Janeiro, Brazil. ${ }^{2}$ Laboratório de Biomedicina do Cérebro- Instituto Estadual do Cérebro Paulo Niemeyer (IECPN), Rio de Janeiro, Brasil. Rua do Rezende, 156 - Centro, Rio de Janeiro, RJ 20231-092, Brasil. In Instituto de Ciências Biomédicas da Universidade Federal do Rio de Janeiro (ICB-UFR), Rio de Janeiro, Brazil. ${ }^{4}$ Faculdade de Medicina da Universidade Federal do Rio de Janeiro, Rio de Janeiro, Brazil. ${ }^{5} \mathrm{KAVI}$ 
Institute of Clinical Research, Faculty of Medicine, University of Nairobi, Nairobi, Kenya.

\section{Received: 4 March 2021 Accepted: 4 November 2021} Published online: 19 November 2021

\section{References}

1. Louis DN, Perry A, Reifenberger G, von Deimling A, Figarella-Branger D, Cavenee WK, et al. The 2016 World Health Organization classification of tumors of the central nervous system: a summary. Acta Neuropathol. 2016; 131(6):803-20 Available from: http://link.springer.com/10.1007/s00401-016-1 545-1.

2. Louis DN, Pomeroy SL, Cairncross JG. Focus on central nervous system neoplasia. Cancer Cell. 2002;1(2):125-8 Available from: http://www.ncbi.nlm. nih.gov/pubmed/12086870.

3. Stupp R, Hegi ME, Mason WP, van den Bent MJ, Taphoorn MJ, Janzer RC et al. Effects of radiotherapy with concomitant and adjuvant temozolomide versus radiotherapy alone on survival in glioblastoma in a randomised phase III study: 5-year analysis of the EORTC-NCIC trial. Lancet Oncol. 2009; 10(5):459-66. Available from: https://linkinghub.elsevier.com/retrieve/pii/S14 70204509700257. https://doi.org/10.1016/S1470-2045(09)70025-7.

4. Stupp R, Mason WP, van den Bent MJ, Weller M, Fisher B, Taphoorn MJB, et al. Radiotherapy plus concomitant and adjuvant temozolomide for glioblastoma. N Engl J Med. 2005;352(10):987-96 Available from: http:// www.nejm.org/doi/abs/10.1056/NEJMoa043330.

5. Gilbert MR, Wang M, Aldape KD, Stupp R, Hegi ME, Jaeckle KA, et al. Dosedense Temozolomide for newly diagnosed glioblastoma: a randomized phase III clinical trial. J Clin Oncol. 2013;31(32):4085-91 Available from: http://ascopubs.org/doi/10.1200/JCO.2013.49.6968.

6. Konrad CV, Murali R, Varghese BA, Nair R. The role of cancer stem cells in tumor heterogeneity and resistance to therapy. Can J Physiol Pharmacol. 2017;95(1):1-15 Available from: http://www.nrcresearchpress.com/doi/10.113 9/cjpp-2016-0079.

7. Nimmakayala RK, Batra SK, Ponnusamy MP. Unraveling the journey of cancer stem cells from origin to metastasis. Biochim Biophys Acta - Rev Cancer. 2019;1871(1):50-63. Available from: https://inkinghub.elsevier.com/ retrieve/pii/S0304419X18301161. https://doi.org/10.1016/j.bbcan.2018.10.006.

8. Semenza GL. Defining the role of hypoxia-inducible factor 1 in cancer biology and therapeutics. Oncogene. 2010;29(5):625-34. Available from: http://www.nature.com/articles/onc2009441. https://doi.org/10.1038/onc.2 009.441.

9. Beig N, Patel J, Prasanna P, Hill V, Gupta A, Correa R, et al. Radiogenomic analysis of hypoxia pathway is predictive of overall survival in Glioblastoma. Sci Rep. 2018;8(1):7 Available from: http://www.nature.com/articles/s41598017-18310-0.

10. Monteiro A, Hill R, Pilkington G, Madureira P. The Role of Hypoxia in Glioblastoma Invasion. Cells. 2017;6(4):45 Available from: http://www.mdpi. com/2073-4409/6/4/45

11. Brat DJ, Castellano-Sanchez AA, Hunter SB, Pecot M, Cohen C, Hammond $\mathrm{EH}$, et al. Pseudopalisades in glioblastoma are hypoxic, express extracellular matrix proteases, and are formed by an actively migrating cell population. Cancer Res. 2004;64(3):920-7 Available from: http://www.ncbi.nlm.nih.gov/ pubmed/14871821.

12. Bar EE, Lin A, Mahairaki V, Matsui W, Eberhart CG. Hypoxia increases the expression of stem-cell markers and promotes clonogenicity in glioblastoma neurospheres. Am J Pathol. 2010;177(3):1491-502. Available from: https://linkinghub.elsevier.com/retrieve/pii/S0002944010602015. https://doi.org/10.2353/ajpath.2010.091021.

13. Yao K, Gietema JA, Shida S, Selvakumaran M, Fonrose X, Haas NB, et al. In vitro hypoxia-conditioned colon cancer cell lines derived from HCT116 and HT29 exhibit altered apoptosis susceptibility and a more angiogenic profile in vivo. Br J Cancer. 2005;93(12):1356-63. Available from: http://www.nature. com/articles/6602864. https://doi.org/10.1038/sj.bjc.6602864.

14. Gaelzer MM, dos Santos MS, Coelho BP, de Quadros AH, Simão F, Usach V, et al. Hypoxic and reoxygenated microenvironment: Stemness and differentiation state in glioblastoma. Mol Neurobiol. 2017;54(8):6261-72 Available from: http://link.springer.com/10.1007/s12035-016-0126-6.

15. Seidel S, Garvalov BK, Wirta V, von Stechow L, Schänzer A, Meletis K, et al. A hypoxic niche regulates glioblastoma stem cells through hypoxia inducible factor 2a. Brain. 2010;133(4):983-95 Available from: https://academic.oup. com/brain/article-lookup/doi/10.1093/brain/awq042.
16. Majmundar AJ, Wong WJ, Simon MC. Hypoxia-inducible factors and the response to hypoxic stress. Mol Cell. 2010;40(2):294-309. Available from: https://linkinghub.elsevier.com/retrieve/pii/S1097276510007501. https://doi. org/10.1016/j.molcel.2010.09.022.

17. Schito L, Semenza GL. Hypoxia-inducible factors: master regulators of cancer progression. Trends in Cancer. 2016;2(12):758-70. Available from: https:// linkinghub.elsevier.com/retrieve/pii/\$2405803316301595. https://doi.org/10.1 016/j.trecan.2016.10.016.

18. Esteller M. Non-coding RNAs in human disease. Nat Rev Genet. 2011;12(12): 861-74. Available from: http://www.nature.com/articles/nrg3074. https://doi. org/10.1038/nrg3074.

19. Lewis BP, Burge CB, Bartel DP. Conserved seed pairing, often flanked by adenosines, indicates that thousands of human genes are MicroRNA targets. Cell. 2005;120(1):15-20. Available from: https://linkinghub.elsevier.com/ retrieve/pii/S0092867404012607. https://doi.org/10.1016/j.cell.2004.12.035.

20. Schwarzenbach H, Nishida N, Calin GA, Pantel K. Clinical relevance of circulating cell-free microRNAs in cancer. Nat Rev Clin Oncol. 2014;11(3): 145-56. Available from: http://www.nature.com/articles/nrclinonc.2014.5. https://doi.org/10.1038/nrclinonc.2014.5

21. Li Y, Guessous F, Zhang Y, DiPierro C, Kefas B, Johnson E, et al. MicroRNA34a inhibits glioblastoma growth by targeting multiple oncogenes. Cancer Res. 2009;69(19):7569-76 Available from: http://cancerres.aacrjournals.org/ cgi/doi/10.1158/0008-5472.CAN-09-0529.

22. Li W-B, Ma M-W, Dong L-J, Wang F, Chen L-X, Li X-R. MicroRNA-34a targets notch1 and inhibits cell proliferation in glioblastoma multiforme. Cancer Biol Ther. 2011;12(6):477-83 Available from: http://www.tandfonline.com/ doi/abs/10.4161/cbt.12.6.16300

23. Wei JS, Song YK, Durinck S, Chen Q-R, Cheuk ATC, Tsang P, et al. The MYCN oncogene is a direct target of miR-34a. Oncogene. 2008;27(39):5204-13. Available from: http://www.nature.com/articles/onc2008154. https://doi. org/10.1038/onc.2008.154.

24. Bommer GT, Gerin I, Feng Y, Kaczorowski AJ, Kuick R, Love RE, et al. p53mediated activation of miRNA34 candidate tumor-suppressor genes. Curr Biol. 2007;17(15):1298-307. Available from: https://linkinghub.elsevier.com/ retrieve/pii/S0960982207016387. https://doi.org/10.1016/j.cub.2007.06.068.

25. Valvona CJ, Fillmore HL, Nunn PB, Pilkington GJ. The regulation and function of lactate dehydrogenase a: therapeutic potential in brain tumor. Brain Pathol. 2016;26(1):3-17 Available from: http://doi.wiley.com/10.1111/ bpa.12299.

26. Chang T-C, Wentzel EA, Kent OA, Ramachandran K, Mullendore M, Lee KH, et al. Transactivation of miR-34a by p53 broadly influences gene expression and promotes apoptosis. Mol Cell. 2007;26(5):745-52. Available from: https:// linkinghub.elsevier.com/retrieve/pii/S1097276507003103. https://doi.org/10.1 016/j.molcel.2007.05.010

27. He L, He X, Lim LP, de Stanchina $E$, Xuan Z, Liang $Y$, et al. A microRNA component of the p53 tumour suppressor network. Nature. 2007:447(7148): 1130-4. Available from: http://www.nature.com/articles/nature05939. https://doi.org/10.1038/nature05939.

28. Sempere LF, Freemantle S, Pitha-Rowe I, Moss E, Dmitrovsky E, Ambros V. Expression profiling of mammalian microRNAs uncovers a subset of brainexpressed microRNAs with possible roles in murine and human neuronal differentiation. Genome Biol. 2004;5(3):R13 Available from: http://www.ncbi. nlm.nih.gov/pubmed/15003116.

29. Cui JG, Zhao Y, Sethi P, Li YY, Mahta A, Culicchia F, et al. Micro-RNA-128 (miRNA-128) down-regulation in glioblastoma targets ARP5 (ANGPTL6), Bmi1 and E2F-3a, key regulators of brain cell proliferation. J Neurooncol. 2010; 98(3):297-304 Available from: http://link.springer.com/10.1007/s11060-0090077-0.

30. Conti A, Aguennouz M, La Torre D, Tomasello C, Cardali S, Angileri FF, et al. miR-21 and 221 upregulation and miR-181b downregulation in human grade II-IV astrocytic tumors. J Neurooncol. 2009;93(3):325-32 Available from: http://link.springer.com/10.1007/s11060-009-9797-4.

31. Ciafrè SA, Galardi S, Mangiola A, Ferracin M, Liu C-G, Sabatino G, et al. Extensive modulation of a set of microRNAs in primary glioblastoma. Biochem Biophys Res Commun. 2005;334(4):1351-8. Available from: https:// linkinghub.elsevier.com/retrieve/pii/S0006291X05014816. https://doi.org/10.1 016/j.bbrc.2005.07.030

32. Miska EA, Alvarez-Saavedra E, Townsend M, Yoshii A, Sestan N, Rakic $P$, et al. Microarray analysis of microRNA expression in the developing mammalian brain. Genome biol. 2004;5(9):R68 Available from: http://www.ncbi.nlm.nih. gov/pubmed/15345052, 2004. 
33. Papagiannakopoulos T, Friedmann-Morvinski D, Neveu P, Dugas JC, Gill RM, Huillard E, et al. Pro-neural miR-128 is a glioma tumor suppressor that targets mitogenic kinases. Oncogene. 2012;31(15):1884-95. Available from: http://www.nature.com/articles/onc2011380. https://doi.org/10.1038/onc.2 011.380 .

34. Zhang Y, Chao T, Li R, Liu W, Chen Y, Yan X, et al. MicroRNA-128 inhibits glioma cells proliferation by targeting transcription factor E2F3a. J Mol Med. 2009;87(1):43-51 Available from: http://link.springer.com/10.1007/s00109008-0403-6.

35. Wuchty S, Arjona D, Li A, Kotliarov Y, Walling J, Ahn S, et al. Prediction of Associations between microRNAs and Gene Expression in Glioma Biology. Rogers S, editor. PLoS One. 2011;6(2):e14681 Available from: https://dx.plos. org/10.1371/journal.pone.0014681.

36. Peruzzi P, Bronisz A, Nowicki MO, Wang Y, Ogawa D, Price R, et al. MicroRNA-128 coordinately targets polycomb repressor complexes in glioma stem cells. Neuro Oncol. 2013;15(9):1212-24 Available from: https://a cademic.oup.com/neuro-oncology/article-lookup/doi/10.1093/neuonc/ not055.

37. Shi L, Cheng Z, Zhang J, Li R, Zhao P, Fu Z, et al. hsa-mir-181a and hsa-mir$181 \mathrm{~b}$ function as tumor suppressors in human glioma cells. Brain Res. 2008; 1236:185-93 Available from: https://linkinghub.elsevier.com/retrieve/pii/ S0006899308018362

38. Slaby O, Lakomy R, Fadrus P, Hrstka R, Kren L, Lzicarova E, et al. MicroRNA181 family predicts response to concomitant chemoradiotherapy with temozolomide in glioblastoma patients. Neoplasma. 2010;57(3):264-9. Available from: http://www.elis.sk/index.php?page=shop.product_deta ils\&flypage=flypage.tpl\&product_id=1907\&category_id=59\&option=com_ virtuemart\&ltemid=1. https://doi.org/10.4149/neo_2010_03_264.

39. Chen Y, Li R, Pan M, Shi Z, Yan W, Liu N, et al. MiR-181b modulates chemosensitivity of glioblastoma multiforme cells to temozolomide by targeting the epidermal growth factor receptor. J Neurooncol. 2017;133(3): 477-85 Available from: http://link.springer.com/10.1007/s11060-017-2463-3.

40. Hu. MicroRNA-181a sensitizes human malignant glioma U87MG cells to radiation by targeting Bcl-2. Oncol Rep. 2010;23(4) Available from: http:// www.spandidos-publications.com/or/23/4/997.

41. Ouyang Y-B, Lu Y, Yue S, Giffard RG. miR-181 targets multiple BCl-2 family members and influences apoptosis and mitochondrial function in astrocytes. Mitochondrion. 2012;12(2):213-9 Available from: https:// linkinghub.elsevier.com/retrieve/pii/S1567724911002820.

42. Liu Y-S, Lin H-Y, Lai S-W, Huang C-Y, Huang B-R, Chen P-Y, et al. MiR-181b modulates EGFR-dependent VCAM-1 expression and monocyte adhesion in glioblastoma. Oncogene. 2017;36(35):5006-22. Available from: http://www. nature.com/articles/onc2017129. https://doi.org/10.1038/onc.2017.129.

43. Ruan J, Lou S, Dai Q, Mao D, Ji J, Sun X. Tumor suppressor miR-181C attenuates proliferation, invasion, and self-renewal abilities in glioblastoma. Neuroreport. 2015;26(2):66-73. Available from: http://content.wkhealth.com/ linkback/openurl?sid=WKPTLP:landingpage\&an=00001756-201501020-00004 https://doi.org/10.1097/WNR.0000000000000302.

44. Kang. Global changes of mRNA expression reveals an increased activity of the interferon-induced signal transducer and activator of transcription (STAT) pathway by repression of miR-221/222 in glioblastoma U251 cells. Int J Oncol. 2010;36(6) Available from: http://www.spandidos-publications.com/ijo/36/6/1503.

45. Gillies JK, Lorimer IAJ. Regulation of p27 Kip1 by miRNA 221/222 in glioblastoma. Cell Cycle. 2007;6(16):2005-9 Available from: http://www.ta ndfonline.com/doi/abs/10.4161/cc.6.16.4526.

46. Banelli B, Forlani A, Allemanni G, Morabito A, Pistillo MP, Romani M MicroRNA in glioblastoma: an overview. Int J Genomics. 2017;2017:1-16. Available from: https://www.hindawi.com/journals/ijg/2017/7639084/. https://doi.org/10.1155/2017/7639084.

47. Jiang C. Downregulation of miR-221/222 sensitizes glioma cells to temozolomide by regulating apoptosis independently of p53 status. Oncol Rep. 2011; Available from: http://www.spandidos-publications.com/10.3892/ or.2011.1535.

48. He L, Thomson JM, Hemann MT, Hernando-Monge E, Mu D, Goodson S, et al. A microRNA polycistron as a potential human oncogene. Nature. 2005; 435(7043):828-33. Available from: http://www.nature.com/articles/nature03 552. https://doi.org/10.1038/nature03552.

49. Lu S, Wang S, Geng S, Ma S, Liang Z, Jiao B. Increased expression of microRNA-17 predicts poor prognosis in human glioma. J Biomed Biotechnol. 2012;2012:1-6 Available from: http://www.hindawi.com/journals/ bmri/2012/970761/.
50. Comincini S, Allavena G, Palumbo S, Morini M, Durando F, Angeletti F, et al. microRNA-17 regulates the expression of ATG7 and modulates the autophagy process, improving the sensitivity to temozolomide and lowdose ionizing radiation treatments in human glioblastoma cells. Cancer Biol Ther. 2013;14(7):574-86 Available from: http://www.tandfonline.com/doi/a bs/10.4161/cbt.24597.

51. Li H, Yang BB. Stress response of glioblastoma cells mediated by miR-17-5p targeting PTEN and the passenger strand miR-17-3p targeting MDM2. Oncotarget. 2012;3(12) Available from: http://www.oncotarget.com/fulltext/ 810.

52. O'Donnell KA, Wentzel EA, Zeller Kl, Dang CV, Mendell JT. c-Myc-regulated microRNAs modulate E2F1 expression. Nature. 2005;435(7043):839-43 Available from: http://www.nature.com/articles/nature03677.

53. Dellago H, Bobbili MR, Grillari J. MicroRNA-17-5p: at the crossroads of cancer and aging - a mini-review. Gerontology. 2017;63(1):20-8. Available from: https://www.karger.com/Article/FullText/447773. https://doi.org/10.1159/ 000447773.

54. Lewis BP, Shih I, Jones-Rhoades MW, Bartel DP, Burge CB. Prediction of mammalian microRNA targets. Cell. 2003;115(7):787-98. Available from: https://linkinghub.elsevier.com/retrieve/pii/S0092867403010183. https://doi. org/10.1016/S0092-8674(03)01018-3.

55. Fuziwara CS, Kimura ET. Insights into regulation of the miR-17-92 cluster of miRNAs in cancer. Front Med. 2015;2 Available from: http://journal. frontiersin.org/Article/10.3389/fmed.2015.00064/abstract.

56. Macharia LW, Wanjiru CM, Mureithi MW, Pereira CM, Ferrer VP, Moura-Neto V. MicroRNAs, hypoxia and the stem-like state as contributors to cancer aggressiveness. Front Genet. 2019;10 Available from: https://www.frontiersin. org/article/10.3389/fgene.2019.00125/full.

57. Muz B, de la Puente P, Azab F, Azab AK. The role of hypoxia in cancer progression, angiogenesis, metastasis, and resistance to therapy. Hypoxia. 2015;83 Available from: https://www.dovepress.com/the-role-of-hypoxia-incancer-progression-angiogenesis-metastasis-and\%2D\%2Dpeer-reviewed-a rticle-HP.

58. Musah-Eroje A, Watson S. A novel 3D in vitro model of glioblastoma reveals resistance to temozolomide which was potentiated by hypoxia. J Neurooncol. 2019;142(2):231-40 Available from: http://link.springer.com/10.1 007/s11060-019-03107-0.

59. Wenger R, Kurtcuoglu V, Scholz C, Marti H, Hoogewijs D. Frequently asked questions in hypoxia research. Hypoxia. 2015;35 Available from: https:// www.dovepress.com/frequently-asked-questions-in-hypoxia-research-peerreviewed-article-HP.

60. Faria J, Romão L, Martins S, Alves T, Mendes FA, de Faria GP, et al. Interactive properties of human glioblastoma cells with brain neurons in culture and neuronal modulation of glial laminin organization. Differentiation. 2006;74(9-10):562-72. Available from: https://linkinghub. elsevier.com/retrieve/pii/S0301468109602437. https://doi.org/10.1111/j.14320436.2006.00090.x.

61. Bradford M. A rapid and sensitive method for the quantitation of microgram quantities of protein utilizing the principle of protein-dye binding. Anal Biochem. 1976;72(1-2):248-54. Available from: http:// linkinghub.elsevier.com/retrieve/pii/S0003269776699996. https://doi.org/10.1 016/0003-2697(76)90527-3

62. Livak KJ, Schmittgen TD. Analysis of relative gene expression data using real-time quantitative PCR and the $2-\Delta \Delta C T$ method. Methods. 2001;25(4): 402-8. Available from: https://linkinghub.elsevier.com/retrieve/pii/S10462023 01912629. https://doi.org/10.1006/meth.2001.1262.

63. Mahotka C, Liebmann J, Wenzel M, Suschek CV, Schmitt M, Gabbert HE, et al. Differential subcellular localization of functionally divergent survivin splice variants. Cell Death Differ. 2002;9(12):1334-42 Available from: http:// www.nature.com/articles/4401091.

64. O'Connor DS, Wall NR, Porter AC, Altieri DC. A p34cdc2 survival checkpoint in cancer. Cancer Cell. 2002;2(1):43-54. Available from: https://linkinghub. elsevier.com/retrieve/pii/\$1535610802000843. https://doi.org/10.1016/S15356108(02)00084-3.

65. Uren AG, Wong L, Pakusch M, Fowler KJ, Burrows FJ, Vaux DL, et al. Survivin and the inner centromere protein INCENP show similar cell-cycle localization and gene knockout phenotype. Curr Biol. 2000;10(21):1319-28. Available from: https://linkinghub.elsevier.com/retrieve/pii/S09609822 00007697. https://doi.org/10.1016/S0960-9822(00)00769-7.

66. Jiang BH, Zheng JZ, Leung SW, Roe R, Semenza GL. Transactivation and inhibitory domains of hypoxia-inducible factor 1alpha. Modulation of 
transcriptional activity by oxygen tension. J Biol Chem. 1997;272(31):1925360 Available from: http://www.ncbi.nlm.nih.gov/pubmed/9235919.

67. Manalo DJ, Rowan A, Lavoie T, Natarajan L, Kelly BD, Ye SQ, et al. Transcriptional regulation of vascular endothelial cell responses to hypoxia by HIF-1. Blood. 2005;105(2):659-69 Available from: http://www.ncbi.nlm.nih. gov/pubmed/15374877.

68. Elvidge GP, Glenny L, Appelhoff RJ, Ratcliffe PJ, Ragoussis J, Gleadle JM. Concordant regulation of gene expression by hypoxia and 2-oxoglutaratedependent dioxygenase inhibition: the role of HIF-1alpha, HIF-2alpha, and other pathways. J Biol Chem. 2006;281(22):15215-26 Available from: http:// www.ncbinlm.nih.gov/pubmed/16565084.

69. Mathieu J, Zhang Z, Zhou W, Wang AJ, Heddleston JM, Pinna CMA, et al. HIF induces human embryonic stem cell markers in cancer cells. Cancer Res. 2011;71(13):4640-52 Available from: http://cancerres.aacrjournals.org/cgi/ doi/10.1158/0008-5472.CAN-10-3320.

70. Heddleston JM, Li Z, McLendon RE, Hjelmeland AB, Rich JN. The hypoxic microenvironment maintains glioblastoma stem cells and promotes reprogramming towards a cancer stem cell phenotype. Cell Cycle. 2009; 8(20):3274-84 Available from: http://www.tandfonline.com/doi/abs/10.4161/ cc.8.20.9701.

71. Özcan E, Çakır T. Reconstructed metabolic network models predict flux-level metabolic reprogramming in glioblastoma. Front Neurosci. 2016;10 Available from: http://journal.frontiersin.org/Article/10.3389/fnins.2016.001 56/abstract.

72. Yuen CA, Asuthkar S, Guda MR, Tsung AJ, Velpula KK. Cancer stem cell molecular reprogramming of the Warburg effect in glioblastomas: a new target gleaned from an old concept. CNS Oncol. 2016;5(2):101-8 Available from: https://www.futuremedicine.com/doi/10.2217/cns-2015-0006.

73. Jain RK, di Tomaso E, Duda DG, Loeffler JS, Sorensen AG, Batchelor TT. Angiogenesis in brain tumours. Nat Rev Neurosci. 2007;8(8):610-22. Available from: http://www.nature.com/articles/nrn2175. https://doi.org/10.1 038/nrn2175.

74. Li J, Ke Y, Huang M, Huang S, Liang Y. Inhibitory effects of B-cell lymphoma 2 on the vasculogenic mimicry of hypoxic human glioma cells. Exp Ther Med. 2015;9(3):977-81 Available from: https://www.spandidos-publications. com/10.3892/etm.2014.2162.

75. Gammoh N, Fraser J, Puente C, Syred HM, Kang H, Ozawa T, et al. Suppression of autophagy impedes glioblastoma development and induces senescence. Autophagy. 2016;12(9):1431-9 Available from: https://www.ta ndfonline.com/doi/full/10.1080/15548627.2016.1190053.

76. O'Connor DS, Wall NR, Porter AC, Altieri DC. A p34cdc2 survival checkpoint in cancer. Cancer Cell. 2002;2(1):43-54. https://doi.org/10.1016/S1535-61 08(02)00084-3.

77. Uren AG, Wong L, Pakusch M, Fowler KJ, Burrows FJ, Vaux DL, et al. Survivin and the inner centromere protein INCENP show similar cell-cycle localization and gene knockout phenotype. Curr Biol. 2000;10(21):1319-28. https://doi.org/10.1016/S0960-9822(00)00769-7.

78. Xie D, Zeng YX, Wang HJ, Wen JM, Tao Y, Sham JST, et al. Expression of cytoplasmic and nuclear Survivin in primary and secondary human glioblastoma. Br J Cancer. 2006;94(1):108-14. https://doi.org/10.1038/sj.bjc. 6602904.

79. Shirai K, Suzuki Y, Oka K, Noda S, Katoh H, Suzuki Y, et al. Nuclear survivin expression predicts poorer prognosis in glioblastoma. J Neuro-Oncol. 2009; 91(3):353-8. https://doi.org/10.1007/s11060-008-9720-4.

80. Saito T, Arifin MT, Hama S, Kajiwara Y, Sugiyama K, Yamasaki F, et al. Survivin subcellular localization in high-grade astrocytomas: simultaneous expression in both nucleus and cytoplasm is negative prognostic marker. J NeuroOncol. 2007:82(2):193-8. https://doi.org/10.1007/s11060-006-9267-1.

81. Jiang B, Liu L. Chapter 2 PI3K/PTEN signaling in angiogenesis and tumorigenesis; 2009. p. 19-65. Available from: https://linkinghub.elsevier. com/retrieve/pii/S0065230X09020028. https://doi.org/10.1016/50065-23 0X(09)02002-8

82. Li P, Zhou C, Xu L, Xiao H. Hypoxia enhances stemness of cancer stem cells in glioblastoma: an in vitro study. Int J Med Sci. 2013;10(4):399-407. Available from: http://www.medsci.org/v10p0399.htm. https://doi.org/10.7 50/ijms.5407.

83. Joseph JV, Conroy S, Pavlov K, Sontakke P, Tomar T, Eggens-Meijer E, et al. Hypoxia enhances migration and invasion in glioblastoma by promoting a mesenchymal shift mediated by the HIF1a-ZEB1 axis. Cancer Lett. 2015; 359(1):107-16 Available from: https://linkinghub.elsevier.com/retrieve/pii/S03 04383515000312 .
84. Erler JT, Bennewith KL, Nicolau M, Dornhöfer N, Kong C, Le Q-T, et al. Lysyl oxidase is essential for hypoxia-induced metastasis. Nature. 2006;440(7088): 1222-6 Available from: http://www.ncbi.nlm.nih.gov/pubmed/16642001.

85. Bos R, Zhong H, Hanrahan CF, Mommers EC, Semenza GL, Pinedo HM, et al. Levels of hypoxia-inducible factor-1 alpha during breast carcinogenesis. J Natl Cancer Inst. 2001;93(4):309-14 Available from: http://www.ncbi.nlm.nih. gov/pubmed/11181778

86. Gee HE, Ivan C, Calin GA, Ivan M. HypoxamiRs and cancer: from biology to targeted therapy. Antioxid Redox Signal. 2014;21 (8):1220-38 Available from: http://www.ncbi.nlm.nih.gov/pubmed/24111776.

87. Loscalzo J. The cellular response to hypoxia: tuning the system with microRNAs. J Clin Invest. 2010;120(11):3815-7. Available from: http://www.jci org/articles/view/45105. https://doi.org/10.1172/JCl45105.

88. Marsit CJ, Eddy K, Kelsey KT. MicroRNA responses to cellular stress. Cancer Res. 2006;66(22):10843-8 Available from: http://cancerres.aacrjournals.org/ cgi/doi/10.1158/0008-5472.CAN-06-1894.

89. Kulshreshtha R, Ferracin M, Wojcik SE, Garzon R, Alder H, Agosto-Perez FJ, et al. A MicroRNA signature of hypoxia. Mol Cell Biol. 2007;27(5):1859-67 Available from: http://mcb.asm.org/cgi/doi/10.1128/MCB.01395-06.

90. Shen G, Li X, Jia Y, Piazza GA, Xi Y. Hypoxia-regulated microRNAs in human cancer. Acta Pharmacol Sin. 2013;34(3):336-41. Available from: http://www. nature.com/articles/aps2012195. https://doi.org/10.1038/aps.2012.195.

91. Levine AJ, Hu W, Feng Z. The P53 pathway: what questions remain to be explored? Cell Death Differ. 2006;13(6):1027-36. Available from: http://www. nature.com/articles/4401910. https://doi.org/10.1038/sj.cdd.4401910.

92. Harris SL, Levine AJ. The p53 pathway: positive and negative feedback loops. Oncogene. 2005;24(17):2899-908. Available from: http://www.nature. com/articles/1208615. https://doi.org/10.1038/sj.onc.1208615.

93. Yan $\mathrm{H}$, Xue G, Mei Q, Wang Y, Ding F, Liu M-F, et al. Repression of the miR17-92 cluster by p53 has an important function in hypoxia-induced apoptosis. EMBO J. 2009;28(18):2719-32 Available from: http://emboj. embopress.org/cgi/doi/10.1038/emboj.2009.214.

94. Tarasov V, Jung P, Verdoodt B, Lodygin D, Epanchintsev A, Menssen A, et al. Differential regulation of microRNAs by p53 revealed by massively parallel sequencing: miR-34a is a p53 target that induces apoptosis and G1-arrest. Cell Cycle. 2007;6(13):1586-93 Available from: http://www.tandfonline.com/ doi/abs/10.4161/cc.6.13.4436

95. Wang X, Chen J, Liu J, You C, Liu Y, Mao Q. Gain of function of mutant TP53 in glioblastoma: prognosis and response to temozolomide. Ann Surg Oncol. 2014;21(4):1337-44 Available from: http://link.springer.com/10.1245/s10434013-3380-0.

96. Wang Y, Yang J, Zheng H, Tomasek GJ, Zhang P, McKeever PE, et al. Expression of Mutant p53 Proteins Implicates a Lineage Relationship between Neural Stem Cells and Malignant Astrocytic Glioma in a Murine Model. Cancer Cell. 2009;15(6):514-26 Availablefrom: https://linkinghub. elsevier.com/retrieve/pii/S1535610809001147.

\section{Publisher's Note}

Springer Nature remains neutral with regard to jurisdictional claims in published maps and institutional affiliations.

Ready to submit your research? Choose BMC and benefit from:

- fast, convenient online submission

- thorough peer review by experienced researchers in your field

- rapid publication on acceptance

- support for research data, including large and complex data types

- gold Open Access which fosters wider collaboration and increased citations

- maximum visibility for your research: over $100 \mathrm{M}$ website views per year

At $\mathrm{BMC}$, research is always in progress.

Learn more biomedcentral.com/submission 